\title{
Making Food Safety an Issue: Internationalized Food Politics and French Public Health from the 1870s to the Present
}

\author{
PATRICK ZYLBERMAN*
}

Food safety is an ever more conflictive issue receiving media attention. "The increased activity of interest groups, the impact of the Common Agricultural Policy and changes in the retail economy have combined to transform [a relatively closed] food policy community into an issue network". ${ }^{1}$ This account of recent changes lacks the historical dimension that might endow it with meaning. It is hardly appropriate to describe the current situation as a reawakening after a long slumber. In France at least, complaints about food safety voiced in numerous newspaper articles echo enduring concerns and a permanent sense of alarm. ${ }^{2}$ In 1957, Demain ran a catalogue of food scares: industrial bread causing eczema; wine adulterated with sulphur anhydride (for safe transportation); eggs and milk feared by doctors to be toxic (because chickens were being fed with chemicals or fish, and cattle with ground up rubbish); and filthy conditions on cattle and poultry farms. Much the same sort of list could have been drawn up early in the century during meetings of the Société Scientifique d'Hygiène Alimentaire (created in 1904), or run in the press following passage of the 1905 Food Adulteration Act, or printed in popular pamphlets such as Dr Raffray's Le péril alimentaire (1912). As the Common Market took shape in the 1960s, repeated articles in the daily newspapers relentlessly focused on the issue of food and public health. In France, arguments were continually framed in the language of the 1905 act. $^{3}$

\footnotetext{
* Dr Patrick Zylberman, CERMES, Campus CNRS,

7 rue Guy-Môquet, 94801 Villejuif Cedex, France.

E-mail: zylberma@vjf.cnrs.fr.

This is an enlarged version of a paper read at the symposium, 'Perspectives on the history of food safety', organized by Anne Hardy in May 2001, at the Wellcome Trust Centre for the History of Medicine at University College London. I would like to express my gratitude to Medical History's editors and referees for their comments and suggestions. The English version has been prepared with the help of Noal Mellott, CNRS, Paris.

${ }^{1}$ M J Smith, 'From policy community to issue network: salomella in eggs and the new politics of food', Public Administration, 1991, 69: 235-55, on p. 235.

${ }^{2}$ For parallel developments in Germany, see $\mathrm{H} \mathrm{J}$ Teuteberg, 'Food adulteration and the beginnings of uniform food legislation in late nineteenth-century Germany', in J Burnett and D J Oddy (eds), The origins and development of food policies in Europe,
}

London, Leicester University Press, 1994, pp. 146-60, p. 146.

${ }^{3}$ A Calas, 'Vos aliments vous empoisonnent', Demain, 28 Feb. 1957. Société d'hygiène alimentaire, etc.: E Kohn-Abrest, 'Sur la jurisprudence en matière d'empoisonnement alimentaire, notamment par les gâteaux à la crème', Ann. Méd. Lég., 1924, 4: 110-18, on pp. 112-16; L Barthe, 'La nouvelle loi sur les fraudes. Sa répercussion sur l'esprit des fraudeurs et des consommateurs', Rev. scient., 1910, 48: 649-53, on pp. 649-50; A Rochaix and A Tapernoux, 'Protection des aliments à la production: campagnes, villes', in $L a$ science de l'alimentation en $1937,2^{\mathrm{e}}$ Congrès Scientifique International de l'Alimentation organized by the Société Scientifique d'Hygiène Alimentaire, Alençon, Imp. Alençonnaise, 1938, pp. F3-F60. Animal feed: E C Aviragnet, 'Inconvénients et dangers du lait des vaches nourries de résidus industriels', Hyg. Viande Lait, 1910, 4: 76-84, and 140-57. Language of 1905 act: see, for instance: L-LGruart, 'Nourritures terrestreset . . chimiques!', Le Figaro, 3-4 Feb. 1962. The Food Adulteration Act was promulgated on 1 August 1905. 


\section{Patrick Zylberman}

The present media focus on this issue is not, therefore, something new. But what about the politicization of food safety? When, given an outbreak of foot-and-mouth disease, the British government suddenly considered, in March 2001, vaccinating potentially exposed animals instead of slaughtering them, this unprecedented policy switch sparked debate. According to the New York Times, "the discussion [was] laden with scientific dispute, political maneuvring, national pride and the bottom-line question of the long-term economic impact of vaccination on powerful farm lobbies". ${ }^{4}$ Since public authorities could not effectively handle the outbreak, a policy field became a politicized issue instead of remaining an ordinary, functional matter of regulation. But was this so very exceptional? Or, on the contrary, had it often happened before? The issue of food safety brings food production techniques and epidemiology face-to-face with culture and politics in a context where national administrations no longer exercise full control. Policy-making about food safety does not just fuel conflicts of interest; it also feeds on radically incommensurable ideas about food, since arguments about technical standards may be grounded in divergent values and opinions about the degree and type of interdependence between values and facts. Standards thus become agonistic in that experts can use them as strategic arguments. This might explain why central authorities have less impact on defining food safety policies than border clashes between national public opinions and conflicting influences and interests-why international public health may well be called "agonistic sanitarianism". 5

Although focusing on food policy through the lens of international relations risks blurring domestic factors in full or in part, it will help us to glimpse the critical role of values in this policy field. Explanations might be formulated in line with the frequently drawn distinction between "high" and "low foreign policy"- the former about national security matters, the latter about secondary issues. This distinction, however, separates all sorts of technical issues from foreign relations in general. True, public health per se did not encroach on the domain of high foreign policy, apart from the significant exception of the western powers' struggle against epidemics in central and eastern Europe in the aftermath of the First World War. At the end of the nineteenth century, the "pork war" (an episode discussed hereafter) between the United States and certain European countries provides us with another exception. "Not even the Spanish-American War", commented James Cassedy, "nor the question of Samoa seemed to disturb United States-German relations as much as the problem of German restrictions on imports of American pork". 6

Public health is all the more likely to interfere with "high foreign policy" when countries are not committed to general rules for dealing with such issues in their own right. For this commitment to be made, an orderly procedure - including a set of sanctions - for discussing grievances and settling misunderstandings among nations must be worked out.

\footnotetext{
${ }^{4}$ A Cowell, 'Vaccination option gains support', International Herald Tribune, 28 March 2001. On foot-and-mouth disease in Britain and related animal health legislation, see J R Fisher, 'The economic effects of cattle disease in Britain and its containment, 1850-1900', Agric. Hist., 1980, 54: 278-94, on pp. 283-4, 288.

${ }^{5}$ Values and facts: L Levidow, 'Precautionary uncertainty: regulating GM crops in Europe',
}

Soc. Stud. Sci., 2001, 31: 842-74, on pp. 845-7. Gray's notion of an "agonistic liberalism" has been provocative: J Gray, Two faces of liberalism, Cambridge, Polity Press, 2000, pp. 105-39.

${ }^{6} \mathrm{~J}$ H Cassedy, 'Applied microscopy and American pork diplomacy: Charles Wardell Stiles in Germany 1898-1899', Isis, 1971, 62: 4-20, on p. 5. 


\section{Making Food Safety an Issue}

Ultimately, such rules and procedures signal that nations recognize that their actions in public health are a matter of mutual concern and not merely of domestic policy. ${ }^{7}$

When did this recognition arise in Europe? How strongly have nations adhered to general rules for food safety? What factors have prevented them from adopting a single orderly procedure for dealing with food safety? Let us examine these three questions. ${ }^{8}$

From 1840, European governments began implementing veterinary measures as part of public health policy, but with reluctance. ${ }^{9}$ Given the increasing consumption of meat, especially in towns, animal health slowly but surely became a major issue. From 1856 to 1877, per capita meat consumption in France increased 45 per cent. From 1870 to 1970, daily meat intake rose more than 400 per cent, from 57 to 245 grams per person. Before 1950 however, animal production in France did not always satisfy demand. In 1877, the country had to import about 10 per cent of its meat. ${ }^{10}$

By the 1860s, the field of animal health had completely changed. Once again, incessant warfare, especially in central Europe and the Balkans, was causing diseases to

\footnotetext{
${ }^{7} \mathrm{R} N$ Cooper, 'Trade policy is foreign policy', Foreign Policy, 1972-3, 9: 8-36, on pp. 19-20.

${ }^{8}$ On European food safety history, see

H J Teuteberg (ed.), European food history, a research review, London, Leicester University Press, 1992.

Since the 1930s, French and Italian historians have approached food mainly through the history of cookery and taste, although topics like under-nutrition or diets in specific social groups have also been studied. See: $\mathrm{J} \mathrm{J}$ Hémardinquer (ed.), Pour une histoire de l'alimentation, Paris, Colin, 1970; B Bennassar and $\mathrm{J}$ Goy (eds), Histoire de la consommation, Annales ESC, 1975, 30: 402-632; J L Flandrin and M Montanari (eds), Histoire de l'alimentation, Paris, Fayard, 1996, pp. 7-15. One important example of a research programme on food in the French social sciences is cited by R Bonnain-Moerdijk, 'L'alimentation paysanne en France entre 1850 et 1936', Etudes Rurales, 1975, 58: 29-49, on p. 29. G Thuillier, 'Note sur les sources de l'histoire régionale de l'alimentation pour la France du XIX ${ }^{\mathrm{e}}$ siècle', in Hémardinquer (ed.), op. cit., p. 222, briefly suggested a research on food adulteration, but very few studies have been conducted since, with the notable exception of J P Aron, 'Sur les consommations avariées à Paris dans la deuxième moitié du XIX ${ }^{\mathrm{e}}$ siècle', in Bennassar and Goy (eds), op. cit., pp. 553-62, and J Léonard, Archives du corps. La santé au XIX ${ }^{e}$ siècle, Rennes, Ouest-France, 1986. Thanks to a grant from the CNRS, the Association Lorraine d'Études Alimentaires organized in Nancy in the 1960s a meeting of historians, geographers and public health doctors around Prof. J Parisot. Among the British historians who have studied the health aspects of food safety are: Burnett and Oddy (eds), op. cit., note 2 above; H Kamminga and A Cunningham (eds), The
}

science and culture of nutrition 1840-1940, Amsterdam, Rodopi, 1995; D Smith (ed.), Nutrition in Britain: science, scientists and politics in the twentieth century, London, Routledge, 1997; A Hardy, 'Food, hygiene, and the laboratory: a short history of food-poisoning in Britain, circa 1850-1950', Soc. Hist. Med., 1999, 12: 293-311; D F Smith and J Phillips (eds), Food, science, policy and regulation in the twentieth century, London, Routledge, 2000; M French and J Phillips, Cheated not poisoned? Food regulation in the United Kingdom 1875-1938, Manchester University Press, 2000.

${ }^{9}$ E Leclainche, Histoire illustrée de la médecine vétérinaire, Paris, Albin-Michel, 1955, vol. 2, p. 110 Not surprisingly, historians have started to study veterinary public health in recent years. See P A Koolmees, 'Veterinary inspection and food hygiene in the twentieth century', in Smith and Phillips (eds), op. cit., note 8 above, pp. 53-68, on p. 53 and references.

${ }^{10}$ Increased meat consumption: G Désert, 'Viande et poisson dans l'alimentation des Français au milieu du XIX ${ }^{\mathrm{e}}$ siècle', in Bennassar and Goy (eds), op. cit., note 8 above, pp. 519-36, on p. 526; G Désert and R Specklin, 'Les réactions face à la crise', in G Duby and A Wallon (eds), Histoire de la France rurale 3. De 1789 à 1914, Paris, Seuil, 1992 [1976], pp. 383-428, on p. 418. Statistics 1856: L J J Lunier in the discussion following A Proust, 'Sur l'exportation des viandes de porc salées d'Amérique et le diagnostic différentiel de la trichinose et de la fièvre typhoïde, au nom d'une commission composée de MM Bouley, Brouardel, Chatin, Colin (d'Alfort), Laboulbène, et Proust rapporteur', Bull. Acad. Méd., 1884, 13: 189-211, on p. 209; Mathieu, 'Rapport sur 


\section{Patrick Zylberman}

spread and disorganizing the few existing veterinary controls. Moreover, the "railway revolution" was stimulating the livestock trade, an additional factor in spreading disease and contaminated meat. The "cattle plague" was most dreaded. Following the importation of a Russian herd in 1865-6, Great Britain had to slaughter more than 500,000 head of cattle. Five years later, the rinderpest epidemic, spread by the Prussian and French armies, ravaged half of the departments in France. The Netherlands was also infected through cattle imported from Britain. Reeling from this "exogenous shock", the British came to associate imports strongly with the disease - an association they had previously neglected. In the British Isles as well as on the continent, animal health became an international issue in its own right. $^{11}$

Meat safety thus centred around the question of border controls. It was the main item on the agenda of the Vienna International Conference organized by Austria and Hungary in March 1872 "in order to establish, against cattle plague, a uniformly conceived set of [animal] health regulations" for all of Europe. Germany, Belgium, France, the United Kingdom, Italy, Romania, Russia, Serbia, Switzerland, and Turkey attended. About half the participants were veterinarians. The Conference had a technical agenda formulated not by the Austrian Ministry of Agriculture but by the Vienna Veterinary Institute. Functional politics could become a substitute for inter-governmental politics. ${ }^{12}$

From the start, the Conference pointed an accusing finger at Russia, the putative origin of cattle plague, and at Romania and Turkey. Moscow proposed certificates of origin and health for its exports, but to no avail. As the western delegations suspected, Russia would remain a permanent source of contamination for central and western Europe. (It would not start trying to cope with rinderpest until the 1880s and would not succeed until 1896.) But could central and western Europe (especially Britain) manage without Russian cattle imports? Repeatedly hit by rinderpest from 1848 into

un projet d'importation en France de bœufs sur pieds de la République Argentine et de l'Uruguay, comme viande de boucherie', Bull. Soc. Centr. Méd. Vét., 1877, 31: 353-61, on p. 354. Statistics 1870-1970: M Gervais, M Jollivet, and Y Tavernier, 'Le progrès et ses difficultés (de 1949 à nos jours)', in G Duby and A Wallon (eds), Histoire de la France rurale 4. Depuis 1914, Paris, Seuil, 1992 [1977], pp. 120-73, on p. 130. On supply and demand: Désert and Specklin, op. cit., p. 418; $\mathrm{G}$ Désert, 'Bilan économique à la veille de la Première Guerre mondiale', in Duby and Wallon (eds), op. cit., vol. 3, p. 437; Mathieu, op. cit., p. 353; Lunier, see Proust, op. cit., p. 209. See also C Thouvenot, 'La viande dans les campagnes lorraines. Évolution d'une habitude alimentaire', Ann. Géogr., 1971, 80: 288-329, on pp. 302-15, and Bonnain-Moerdijk, op. cit., note 8 above, p. 45.

${ }^{11}$ Animal health: Anon., 'La peste bovine dans l'Europe occidentale', Rev. scient., 1877, 12: 1168-70, p. 1169-70; Leclainche, op. cit., note 9 above, p. 109. Railway revolution: Rev. scient., 1877, p. 1168; Désert, in Duby and Wallon (eds), op. cit., note 10 above, vol. 4, p. 433. Britain 1865-6: Anon., 'Discussion sur la peste bovine', Bull. Soc. Méd. Yonne, 1872, 13: vi-ix, on p. vii. According to Fisher (op. cit., note 4 above, p. 287), Cheshire lost two-thirds of its cattle between 1865 and 1867. From 1850 to 1870 , British farmers suffered average annual losses due to mortality of 5 per cent, ibid., p. 291. France 1871: M Sinoir, 'Rapport sur l'épizootie de typhus dans la Mayenne en 1871', J.méd. Mayenne, 1 May 1873, pp. 17-32, on pp. 18-21; Leclainche, op. cit., p. 113. Netherlands: H Bouley, 'Des mesures prises contre la peste bovine', L' Union médicale, 1872, 13: 7-9, on p. 8. Exogenous shock:

Fisher, op. cit., note 4 above, p. 279.

${ }^{12}$ Animal health regulations: H Bouley, 'Rapport sur la conférence sanitaire internationale tenue à Vienne (Autriche), en 1872, concernant la peste bovine', Recueil des travaux du Comité Consultatif d'Hygiène Publique, 1873, 2: 403-25, p. 403. Vienna Veterinary Institute: ibid., p. 406. Functional politics: T G Weiss and R S Jordan, 'Bureaucratic politics and the World Food Conference: The international policy process', World Politics, 1976, 28: 422-39, on p. 439. 


\section{Making Food Safety an Issue}

the 1870s, Austria and Hungary had to slaughter cattle. Austria, in particular, needed Russian cattle which local producers fattened. As the French delegate bluntly put it, economic necessity came first; public health, second. But what could be done with countries like Russia which did not care about public health or were not capable of improving the health of their herds? Nothing much apart from border controls. Throughout the nineteenth century, "civilized" states were increasingly expected to have a territorial organization and police borders in order to protect the population from the biological hazards originating in other states. They thus soon turned to using veterinary measures to protect public health. ${ }^{13}$

The Conference split into uneven camps. Germany alone asked for the banning of all cattle imports and the slaughter of all infected animals. Other participants wanted to organize a cordon sanitaire along Austria's eastern border and quarantine imported cattle. In 1877, Britain adopted measures of this sort, after attempts at inoculating cattle in 1866 had failed completely. The policy of slaughtering cattle would not be fully accepted right away (not till the 1890s) given the stiff opposition from foreign cattle traders and urban MPs, who spoke in the name of consumers. In France, sanitary police measures were difficult to enforce-in particular, peasants, veterinarians and even mayors strongly opposed the slaughter of large numbers of sick animals. ${ }^{14}$

The attitude of the French representative, Henry Bouley, a veterinarian (and one of Pasteur's first companions), was a rough mixture of principles and pragmatism-what some might call hypocrisy. This staunch liberal approved the "regionalization principle" discussed at the Conference, which derived from a convention signed earlier in Mannheim between some southern German states. Under this principle, quarantine would be restricted to the province(s) attacked by the disease, instead of being extended to the whole country. Bouley's position becomes more credible when we learn that he reported to his minister that the very efficient measures taken at Germany's eastern borders and at the borders of the different states in the Reich would keep French herds safe from rinderpest, and French meat cheap. ${ }^{15}$ The standard of "civilization" tended to foster the illusion that sanitary and national borders coincide, whereas they may lie wide apart.

The Conference's general purpose — when Austria decided to organize the meeting-was to reach an international agreement on a "uniform sanitary police" and on the compulsory

\footnotetext{
${ }^{13}$ Austria and Hungary: Leclainche, op. cit., note 9 above, pp. 112, 114; Bouley, op. cit., note 12 above, pp. 407, 421. French delegate: ibid., p. 410. Veterinary measures: H Martel,

'L'inspection des viandes dans ses rapports avec la prophylaxie des maladies. Types d'organisation des services', Rev. scient., 1908, 10: 393-8, on p. 398.

${ }^{14}$ Germany: Bouley, op. cit., note 12 above, pp. 410, 407. Austria's eastern border: ibid., p. 410. Britain: Anon., 'La peste bovine', op. cit., note 11 above, p. 1169. Inoculation in 1866: Bouley, op. cit., p. 7. Opposition to slaughter: Fisher, op. cit., note 4 above, p. 286. France: Bouley, op. cit.,
}

note 11 above, p. 8; Anon., 'Discussion', op. cit., note 11 above, pp. vii-viii; Sinoir, op. cit., note 11 above, pp. 27-9.

${ }^{15}$ Bouley, op. cit., note 12 above, pp. 416-17, p. 422. Henry-Marie Bouley (1814-1885), professor of pathological surgery at Maisons-Alfort and general veterinary inspector, had been sent to Britain from 1865 until 1867 by the French government in order to study cattle diseases. A member of the National Academy of Sciences (in 1868) and of the Consultative Committee on Animal Health, he succeeded, in 1879, Claude Bernard in the chair of comparative pathology at the National Museum of Natural History, a position he held until his death. 


\section{Patrick Zylberman}

notification by states of cases of rinderpest, but an agreement which would allow free trade among countries adhering to a single set of rules and practices. Though never published, this agreement would form the basis for all subsequent regulations. ${ }^{16}$ From the mid-1860s to the mid-1870s, the cattle plague provided Europe with an historical opportunity, as the continent came to realize that food safety was not just a domestic issue.

\section{II}

Rinderpest does not directly cause human casualties. In fact, people turned to eating beef in the middle of epizootics in 1857 and 1870-1 because prices had fallen sharply_- "without any inconvenience for health", it was said. ${ }^{17}$

Even as animal health became a concern for governments, owing to increased meat consumption, hygienists became ever more wary of changes in the ways of preparing and eating meat. City-dwellers and peasants as well were now eating foods, such as ham or offal, that they had previously refused. The typical peasant lunch included strips of ham or bacon, lean as well as fat. As a local pig-keeping economy continued unabated, this pork-based diet prevailed until the First World War. Town labourers also ate salt pork, usually fried rather than boiled. Rural-dwellers stayed on fatty diets well into the 1950s, whereas townspeople were developing a taste for grilled and roasted meat. More and more people were consuming undercooked meat. Doctors even advised eating red meat. Horse meat (which was never eaten raw) was considered to be less liable to helminthic infestations and, since it was cheap, they recommended it for tuberculous victims. $^{18}$

Trichinosis provides us with a case in point for this zoonosis perspective. It shows, once again, how important borders were, and still are, in regulating animal diseases that carry risks for people. A helminthiasis transmitted by eating undercooked or raw meat containing trichinae (Trichinella spiralis) larvae, trichinosis causes digestive and muscular symptoms, and can lead to fatal neurological and heart complications. ${ }^{19}$

In the late 1870 s, salt-cured meat from the United States was flooding the European, especially the French, market (see Table 1). ${ }^{20}$ As we have just seen, pork was a major foodstuff among town labourers and country-dwellers. Suddenly, in January 1881, a

\footnotetext{
${ }^{16}$ Uniform sanitary police: Bouley, op. cit., note 12 above, p. 417. Never published: Leclainche, op. cit., note 9 above, p. 198.

${ }^{17}$ Thouvenot, op. cit., note 10 above, p. 300.

${ }^{18}$ Ham: Proust, op. cit., note 10 above, pp. 205-6. Rejected: Rochaix and Tapernoux, op. cit., note 3 above, p. 20; Thouvenot, op. cit., note 10 above, p. 318 Peasant's lunch: J Chatin in the discussion following Proust, op. cit., note 10 above, pp. 240-2. Country/ town: Thouvenot, op. cit., pp. 297, 318-20; BonnainMoerdijk, op. cit., note 8 above, pp. 35-8. Doctors and red meat: $\mathrm{H}$ Larrey in the discussion following A Laboulbène, 'Relation de la première épidémie de trichinose constatée en France', Bull. Acad. Méd., 1881, 10: 206-28, on p. 228; M Laborde, 'La trichine et la trichinose', La Tribune Médicale, 1884, 15: 139-41, 164-5, 174-6, on p. 165; E Sacquépée, 'Études
}

sur les empoisonnements alimentaires provoqués par les salmonelloses', Ann. Hyg., 1911, 4s., 16: 385-422, on p. 409. Horse meat: ibid., p. 402; Thouvenot, op. cit., p. 325; Léonard, op. cit., note 8 above, pp. 171-2.

${ }^{19} \mathrm{~S}$ Haeghebaert and colleagues, 'Épidémie de trichinellose région Midi-Pyrénées', Bull. Épidém. Hebdo., 1998, no. 28: 121-2, on p. 122; S Debrot and A Constantin, Hygiène et protection de la viande, Paris, Maloine, 1968, p. 247.

${ }^{20}$ European market: E Nocard and E Leclainche, 'Epizooties (maladies transmissibles des animaux à l'homme)', in J Rochard (ed.), Encyclopédie d' hygiène et de médecine publique, Paris, Rousseau et Vigot, 1891, vol. 2, ch. 6, p. 171; statistics in Proust, op. cit., note 10 above, p. 196. French market: O du

Mesnil, 'Les mesures administratives prises contre la 


\section{Making Food Safety an Issue}

\section{Table 1}

French salt pork imports by origin (thousand metric tons)

\begin{tabular}{rccccr}
\hline & United States & Britain & Germany & Others & Total \\
\hline 1876 & 3.2 & 1.8 & 0.7 & 1.0 & 6.7 \\
1877 & 12.4 & 1.8 & 0.9 & 1.0 & 16.1 \\
1878 & 28.1 & 1.4 & 0.9 & 1.3 & 31.7 \\
1879 & 31.7 & 1.1 & 1.0 & 1.7 & 35.5 \\
1880 & 34.2 & 1.2 & 0.8 & 2.3 & 38.5 \\
1881 & 17.1 & 0.6 & 0.7 & 1.1 & 19.5 \\
1882 & 0.004 & 1.1 & 1.0 & 1.0 & 3.1 \\
1883 & 0.05 & - & 1.1 & 2.0 & 3.1 \\
\hline
\end{tabular}

Source: A Proust, 'Sur l'exportation des viandes de porc salées d'Amérique et le diagnostic différentiel de la trichinose et de la fièvre typhoïde, au nom d'une commission composée de MM Bouley, Brouardel, Chatin, Colin (d'Alfort), Laboulbène, et Proust rapporteur', Bull. Acad. Méd., 1884, 13: 189-211, on p. 210.

"genuine panic" broke out in France. The previous November, trichinae had, in Lyons and Paris, been found in fifty boxes of bacon strips from New York. The press soon picked up the story. From 1859 to 1877 , there had been sixty-six serious outbreaks of trichinosis in Germany, and many deaths. The most serious outbreak occurred in 1864, in Hedersleben, a small town where 101 out of 337 infected persons died. By 1877, the panic was sweeping through Europe. Except for Belgium and Great Britain, most countries prohibited the import of American salt-cured meat. ${ }^{21}$

France was thought to be safely protected thanks to its "cooking habits". Unlike the Germans, the French supposedly ate thoroughly cooked meat, and no death could be attributed to infested ham or bacon. None the less, as the panic spread, the authorities resorted to prohibiting imports. From 1878 to 1881, no trichinosis was reported in the more than 100 million kilograms of American pork imported into France. But consumers turned away from salt pork, including that of US origin. ${ }^{22}$

trichinose', Ann. Hyg., 1881, 3s., 5: 238-46, on p. 238; $\mathrm{C}$ Leblanc, and $\mathrm{J}$ Chatin in the discussion following Laboulbène, op. cit., note 18 above, p. 221;

$\mathrm{J}$ Rochard in the discussion following $\mathrm{J}$ Chatin, 'Rapport sur un mémoire de M. le Docteur Decaisne, concernant la prohibition des viandes américaines', Bull. Acad. Méd., 1882, 2s., 11: 130-45, on p. 141.

${ }^{21}$ Main food: Thouvenot, op. cit., note 10 above, p. 291; Bonnain-Moerdijk, op. cit., note 8 above, p. 33. Pork still ranked high in diets in the 1960 s, when steak became very popular, Thouvenot, op. cit., p. 324. French boycott of American pork: B Duncan,

'Protectionism and pork: Whitelaw Reid as diplomat 1889-1891', Agric. Hist., 1959, 33: 190-5;

J L Gignilliat, 'Pigs, politics, and protection: the European boycott of American pork 1879-1891',
Agric. Hist., 1961, 35: 3-12, pp. 6-8; and J D Ellis, The physician-legislators of France: medicine and politics in the early Third Republic

1870-1914, Cambridge University Press, 1990, pp. 198-9; also Cassedy, op. cit., note 6 above. Panic: Anon., 'À la Chambre des Députés. De l'importation et de l'inspection des viandes de porc de provenance étrangère', Echo Soc. Ass. Vét. de France, 1882, 4: 185-213, 249-65, p. 256.

Fifty boxes: Laboulbène, op. cit., note 18 above, p. 207. Hedersleben: Anon., 'De l'importation et de l'inspection', op. cit., p. 195; Anon., 'La trichinose et les décrets prohibant l'importation en Europe des viandes salées d'Amérique', Rev. Sanit. Bordeaux, 1883, 1: 1-5, on p. 2.

${ }^{22}$ Cooking habits: H Bouley, 'Viandes de porc de provenance américaine; décret de prohibition motivé 


\section{Patrick Zylberman}

In fact, the risk was real. According to the chief veterinarian of the Department of the Seine (which included Paris), meat inspection agencies fell into one of three categories: 1) those with centralized, technical services that relied on ad hoc arrangements; 2) those that conducted incomplete inspections in order to facilitate exports; 3) rudimentary services managed by local authorities. At the turn of the century, Belgium and Germany fell into the first group; New Zealand and Denmark, into the second; Great Britain and France, into the third. France did not manage fully to centralize meat inspection: neither the law of 21 June 1898 (Code rural) nor the 8 January 1905 slaughterhouse act provided for a uniform service throughout the nation. Meanwhile municipal authorities did not welcome veterinarians, at least not until after a 22 January 1919 decree (in application of the 1905 Food Adulteration Act) that granted the latter full powers to undertake controls in stores, trucks, slaughterhouses and meat-processing facilities. ${ }^{23}$

But what about meat inspection services in the United States? The practices of the American meat industry were far from honest, let alone sanitary, as Upton Sinclair so capably pointed out. In Chicago, the municipality supervised-lightly-the meat-packing industry. Meat-packers opposed federal inspections. As of 1890-1, inspection was restricted to salt pork exports. An act of 30 August 1890 exempted freshly slaughtered carcases from inspection. Inspection did not become mandatory until President Harrison signed a new act on 3 March 1891. But the 1906 Pure Food and Drugs Act abandoned an 1895 regulation that required examining hogs for trichinae. Yet hog infestation was rife, as D E Salmon, the veterinarian who headed the Bureau of Animal Industry, had frankly admitted in 1883. In the 1940s, studies of muscle samples taken from autopsies would show that 16 per cent of persons in the United States were carrying trichinae and that 10 to 20 persons died each year from trichinosis. ${ }^{24}$

Along with other countries, the United States, Austria and Denmark paid no heed to health dangers in foodstuffs. Denmark only made meat inspection mandatory in 1903-6,

par la présence de la trichine;-Doit-il être maintenu?-Y a-t-il lieu de soumettre les viandes de provenances étrangères à une inspection microscopique si le décret de prohibition n'est pas maintenu?' Recueil des Travaux du Comité Consultatif d'Hygiène Publique, 1883, 12: 243-7, on pp. 245-6. Contrast with Germany: Anon., 'La trichinose et les décrets', op. cit., note 21 above, p. 5. No deaths: E Vallin, 'Les trichines devant le Sénat', Ann.Hyg., 1882, 4: 545-53, on pp. 546, 548. No case: Gignilliat, op. cit., note 21 above, p. 7. 100 million kilograms: S Hoy and W Nugent, 'Public health or protectionism? The German-American pork war 1880-1891', Bull. Hist. Med., 1989, 63: 198-224, on p. 215.

${ }^{23}$ Inspection categories: Martel, op. cit., note 13 above, pp. 393-7; H O'Neill, 'Meat inspection in England, France and Germany', Sanit. Rec., 1900, 26: 563-5, on pp. 563-4. Centralization: Martel, op. cit., p. 397; M L Panisset, 'À propos de l'organisation en France d'un contrôle sanitaire des denrées alimentaires d'origine animale', Hyg. Géné. Appliq., 1906, 1: 601-15, pp. 603-10. The 1919 decree: M J Rennes, 'L'inspection des viandes n'existe pas en France', Recueil Méd. Vét., 1920, 96: 534-44, on p. 541. The
5 April 1884 law made meat inspection mandatory for municipalities, but without covering the costs of inspections (Rennes, op. cit., p. 536).

${ }^{24}$ Upton Sinclair: J H Young, 'The pig that fell into the privy: Upton Sinclair's The Jungle and the meat inspection amendments of 1906', Bull. Hist. Med., 1985, 59: 467-80, on pp. 470, 475-7. Chicago: Hoy and Nugent, op. cit., note 22 above, pp. 201, 212. US regulations: Martel, op. cit., note 13 above, p. 396; Hoy and Nugent, op. cit., p. 217. The 1906 Pure Food and Drugs Act was accompanied by a new, more stringent Meat Inspection Law (ibid., p. 223). For more on American pure food regulations, see: W J Darby, 'Historical overview of the safety of the food supply. Introduction', J. Nutr., 1993, 123: 277-8, on p. 277, Table 1; and Anon., 'Public health, nutrition and food safety 1900-1999', Nutr. Rev., 1999, 57: 368-72, on p. 370. Hog infestation: Anon., 'La trichinose et les décrets', op. cit., note 21 above, p. 2. D E Salmon: Hoy and Nugent, op. cit., pp. 212-13. Trichinae in 1940s: Anon., 'Public health, nutrition', op. cit., p. 370. 


\section{Making Food Safety an Issue}

after an MP's family was infected by trichinae. The German Reichtag repealed, in 1900, the hard-and-fast regulations drawn up by Prussia in 1883; searching for trichinae was no longer mandatory. Furthermore, veterinarians had come to doubt the cost-effectiveness of inspections based on the microscope. ${ }^{25}$

In sharp contrast with Germany, pigs bred in France were rarely infested; and this is still the case today. This idea, though sometimes questioned, was widespread when the panic started. Only foreign meats imported from risky areas were inspected. In 1968, this was still standard procedure! The first-and apparently only—trichinosis epidemic inside France occurred in 1878 in Crépy-en-Valois, a small town not far from Paris (one death out of eighteen cases); but it went unnoticed. By contrast, the "American" event as the Revue sanitaire de Bordeaux rightly called it, aroused feelings precisely "because of its international character". ${ }^{26}$

Popular views were muddled. Liberals staunchly advocated bans. Much to the sorrowful surprise of some veterinary associations, the Academy of Medicine was shifting debate away from public health towards a bitter argument over economic policy. Conversely, the Senate turned from a political assembly into a public health chamber. It even held hearings with the chairman (a senator) of the important Consulting Committee of Public Hygiene to discuss epidemiology. ${ }^{27}$

On 15 February 1881 at the French Academy of Medicine, Bouley called for the blocking of US meat at the borders. A year later, he was still arguing: in order to "help the US ... be firmly committed to stop exporting cargoes of pork infested with trichinosis to France", it would be up to importers to adopt "tough measures of defence" at their maritime and land borders. At a meeting of the Society of Public Medicine however, M Laborde, a "pure" hygienist, lamented that trichinosis was "too exclusively seen and dealt with as a border issue... and too much linked with American imports", which represented "a mere accident". ${ }^{28}$ The call for restrictions on American imports followed a 14 February letter to the prefects by Pierre Tirard, Minister of Agriculture, a letter based on three reports by Bouley. These reports recommended avoiding bans and inspecting cargoes at borders while better informing the public (via a poster to be hung in retail shops where salt pork was sold). But Bouley soon called for tougher measures. After all, Germany had banned imports of American ground (minced) pork a few months earlier. On 18 February, under pressure from public opinion and parliament, the Ministry of Agriculture issued a decree prohibiting imports of US salt-cured meat.

\footnotetext{
${ }^{25}$ Austria, Denmark: Anon., 'La trichinose et les décrets', op. cit., note 21 above, p. 2; H Martel, 'Les viandes foraines', Hyg. Géné. Appliq., 1906, 1: 340-54, on p. 351; Martel, op. cit., note 13 above, p. 396. Germany: ibid., pp. 395, 346. Teuteberg (op. cit., note 2 above, pp. 148-9) had a more favourable view. Doubts: Cassedy, op. cit., note 6 above, p. 19.

${ }^{26}$ French hog infestation: Haeghebaert, et al., op. cit., note 19 above, p. 123; C J Davaine, 'Les trichines et la trichinose', Bull. Acad. Méd., 1881, 10: 249-58, on p. 250; Vallin, op. cit., note 22 above, p. 548. Low incidence questioned: G C Colin (d'Alfort), 'Sur les trichines', Bull. Acad. Méd., 1881, 10: $238-49$, on p. 246; Chatin, op. cit., note 20 above,
}

p. 132; Laborde, op. cit., note 18 above, pp. 139-40, 164. Still in 1968: Debrot and Constantin, op. cit., note 19 above, p. 247. Crépy-en-Valois: Davaine, op. cit., p. 250; Proust, op. cit., note 10 above, p. 197; Anon., 'La trichinose et les décrets', op. cit., note 21 above, p. 2.

${ }^{27}$ Academy of Medicine: Anon., 'De l'importation et de l'inspection', op. cit., note 21 above, pp. 185, 187. Senate: Vallin, op. cit., note 22 above, pp. 547-50.

${ }^{28}$ Bouley in the discussion following Laboulbène, op. cit., note 18 above, pp. 216-17; Bouley, op. cit., note 22 above, p. 245. Laborde, op. cit., note 18 above, pp. 139, 141. 


\section{Patrick Zylberman}

About a year later, again at the Academy, Bouley none the less lost patience when it was pointed out that he had been one of the main supporters of the prohibition. ${ }^{29}$

These repeated reversals of policy provide evidence of how poorly the crisis was being managed. At the Society of Public Medicine, the failure of officials, including the Academy of Medicine, to act was condemned by invoking the "evangelical principle"-do not recommend to others what you would not eat yourself-a principle that deputies and senators had advantageously used against leading hygienists. Of course, powerful social forces supported the meat ban: farmers' associations (such as the Société Nationale des Agriculteurs), butchers, meat-packers and, last but not least, deputies. The Senate, where rural interests prevailed, was especially vociferous: back-benchers shouted that the salt pork industry and public health doctors were poisoning food. This fanatical anger arose out of a persistent superstition that, even in the late twentieth century, sociologists still observed in popular opinion (for instance, the "rumour of Villejuif"). Though staffed with protectionist zealots, the Ministry of Foreign Affairs surprisingly took a stand against prohibition in order to improve trade relations with the United States. Chambers of Commerce were divided: Bordeaux and Le Havre, where importers were enrolled, opposed the decree, whereas Nantes, the French pork-packing centre, strongly supported it. Importers did their best to have the decree repealed. A few years later, on 23 November 1883, the government, which had always been inclined to lift the ban, backed their efforts, but to little avail since parliament adamantly opposed repeal till January 1892. More significantly, public health pundits were to join the cause of repeal. ${ }^{30}$

In the French armed forces, as well as in villages and industrial urban centres, the demand for US salt pork remained strong. None the less, this did "not mean that trichinosis has become a French disease", in Bouley's words. Ultimately, meat inspection would be "recommended". Inspectors with microscopes were sent to major ports where US freight was unloaded. It is questionable how effective they were. They took six months to examine 20,000 tons of bacon seized by customs officers at Le Havre, where three-quarters of the meat came in. Inspection turned up a 3 per cent infection

\footnotetext{
${ }^{29}$ Given how public health institutions used to operate in France, it is very unlikely (contrary to Gignilliat, op. cit., note 21 above, p. 7) that the Minister of Agriculture could have asked for a non-governmental scientific inquiry; cf. note 48. On France's public health institutions, see: Ellis, op. cit., note 21 above; and L Murard and P Zylberman, L'Hygiène dans la République. La santé publique en France ou l' utopie contrariée (1870-1918), Paris, Fayard, 1996. Retailers:

Proust, op. cit., note 10 above, p. 206. The reports of the Consulting Committee of Public Hygiene were published on 4 Aug. 1879, 6 Sept. 1880, and 7 Feb. 1881: Bouley, op. cit., note 22, p. 243. Avoiding prohibition: du Mesnil, op. cit., note 20 above, p. 243; Bouley, op. cit., pp. 245-6. Decree of 18 Feb. 1881: Anon., 'De l'importation et de l'inspection', op. cit., note 21 above, p. 257. Main supporter: Bouley in the discussion following Chatin, op. cit., note 20 above, pp. 138-9.
}

\footnotetext{
${ }^{30}$ Society of Public Medicine: 'De l'importation et de l'inspection', op. cit., note 21 above, p. 249. Deputies versus hygienists: Vallin, op. cit., note 22 above, p. 550. Ban's supporters: 'De l'importation et de l'inspection', op. cit., pp. 203-11, 257; J H Gibert in the discussion following Proust, op. cit., note 10 above, pp. 242-3. Vociferous Senate: Vallin, op. cit., pp. 547-8. Villejuif: J N Kapferer, 'A mass poisoning rumor in Europe', Public Opin. Q., 1989, 53: 467-81. Foreign Affairs: Duncan, op. cit., note 21 above, p. 191; Gignilliat, op. cit., note 21 above, p. 7. Chambers of Commerce: ibid., p. 7. Importers for repeal: Vallin, op. cit., p. 546. Government for repeal: Duncan, op. cit., p. 191; Gignilliat, op. cit., pp. 7-8. Public health pundits: 'De l'importation et de l'inspection', op. cit., pp. 213, 258; Vallin, op. cit., pp. 545, 547; Proust, op. cit., p. 199.
} 


\section{Making Food Safety an Issue}

rate. In Paris and Lyons the figure rose to 8 per cent; but in Marseilles the results yielded a tiny 0.33 per cent. The microscopes were perhaps less to blame for these findings than the poor training of inspectors. ${ }^{31}$

Public health experts ultimately came down on the side of economic liberalism. Apart from the fact that American ground meat was cheaper, their main reason was the extremely few fatalities due to trichinae-in fact, next to none. For public health doctors, the panic was making a mountain out of a molehill. Their main argument, however, seemed to centre around the ban's ineffectiveness. Driven out of the ports, Yankee ham was illegally entering France through Germany and Belgium. Belgium imported it from England, where many of the cargoes refused entry in France ended up. There the meat was cut up and repackaged under a new, "innocent" label. ${ }^{32}$

Some public health experts thought that the time had come for international agreements to be worked out in order to improve sanitary standards in meat-packing plants. In 1884, Prof. A Proust, technical adviser to the Minister of the Interior, suggested that "a formal agreement between the United States and the French Republic" be signed. ${ }^{33}$ Plants in Chicago or Cincinnati were to issue certificates, validated by the French consul, stating that their products had been prepared in compliance with standards of hygiene-like the health "patent" required from ships' captains in compliance with cholera regulations. Although the Minister of Agriculture commented that the proposed certification arrangements would be unworkable, public health doctors continued advocating them-as did some members of the government, such as Léon Gambetta, who became Prime Minister in November 1881. Experts wanted this field of "low politics" to rise into the sphere of international law and diplomacy. Since importing countries had no means of monitoring industry standards and regulatory agencies abroad, however, such certificates would have had little value. Much the same discussion had already taken place at the 1872 Vienna rinderpest conference. By the 1890s, importing countries had their own scientific experts to assess other countries' sanitary arrangements; but lack of information (about how to use microscopes, for example) tended to impair assessments. Eighty-five years later, article 30 of the Treaty of Rome (1957) would trigger lively debate about extra-governmental

\footnotetext{
${ }^{31}$ Recommended: Anon., 'La trichinose et les décrets', op. cit., note 21 above, p. 5 . Inspectors in ports: Chatin, op. cit., note 20 above, p. 131; Anon., 'De l'importation et de l'inspection', op. cit., note 21 above, pp. 201, 257; Vallin, op. cit., note 22 above, p. 545. Results using microscopes: Davaine, op. cit., note 26 above, p. 258; 'De l'importation et de l'inspection', op. cit., pp. 257-8; C Livon, 'Quelques réflexions à propos des travaux de la commission chargée d'examiner les viandes de porc de provenance américaine', Marseille Médical, 1881, 18: 537-43, on pp. 537-8. In 1923, according to Rochaix and Tapernoux (op. cit. note 3 above, p. 18), if lay inspectors had at that time used microscopes for inspections, the rate of error would have been nearly 33 per cent.

${ }^{32}$ Siding with liberalism: Vallin, op. cit., note 22 above, p. 547. Fatalities: ibid., p. 548; Davaine, op. cit., note 26 above, pp. 251-2; Proust in the discussion
}

following Chatin, op. cit., note 20 above, pp. 136, 138; Dr de Pietra Santa, 'Trichine et trichinose à l'Académie de Médecine de Paris', J. d'Hyg., 1881, 6: 109-15, p. 115. Prohibition ineffective: Davaine, op. cit., p. 251; Vallin, op. cit., p. 550; Leblanc in the discussion following Chatin, op. cit., pp. 139-40; Proust, op. cit., note 10 above, p. 198. Belgian middlemen made considerable profit from American pork (Gignilliat, op. cit., note 21 above, 8).

${ }^{33}$ Achille Adrien Proust (1834-1903) was appointed chef de clinique at the Paris hospital La Charité, in 1862 . He was elected to the Academy of Medicine in 1879, became general inspector of Sanitary Services (Ministry of the Interior) in 1884, and occupied the chair of Public Health at the Paris Faculty of Medicine in 1885. 


\section{Patrick Zylberman}

Table 2

Causes of food-poisoning, France 1920-58

\begin{tabular}{lrcccc}
\hline & Cases & \% of Total Cases & Outbreaks & Deaths & $\%$ of Deaths \\
\hline Salmonellae & 692 & 25.4 & 17 & 8 & 1.1 \\
Staphylococci & 490 & 18.0 & 10 & 2 & 0.4 \\
Botulism & 1000 & 36.7 & $500^{1}$ & 15 & 1.5 \\
Histamine & 540 & 19.8 & 7 & 0 & 0
\end{tabular}

${ }^{1}$ All outbreaks reported between 1940 and 1945.

Sources: M A Pointeau-Pouliquen, Les causes des intoxications alimentaires en France depuis 1920, Paris, Arnette, 1958, p. 52; R Legroux, C Jéramec and J-C Levaditi, 'Statistique du botulisme de l'Occupation 1940-1944', Bull. Acad. Méd., 1945, 129: 643-5, on p. 644.

supervision-a still unsettled issue, as can be seen in recent EU regulations about offal. "Hygiene demands protection, not protectionism", as the Revue Sanitaire de Bordeaux would state shortly after the pork panic had passed. But who was supposed to protect food? Besides producers, consumers are necessary for action in favour of protection.

Let us take the example of preventing salmonella-related risks. In sharp contrast with previous periods, rather mild outbreaks have occurred during the twentieth century. In 1958, the situation in France was described as anything but serious: despite an increase in cases of salmonellosis, the number of fatalities had decreased, except among the new-born. ${ }^{35}$ A quick look at the 1996-7 statistics is convincing (see Tables 2 and 3).

Staphylococcic infections increased sharply after the Second World War; the ten outbreaks in Table 2 were all reported after 1949. By contrast, botulism, rather frequent in the nineteenth century, decreased remarkably during the twentieth, except for during the war. These two tables are considerably biased owing to both the many unreported (even unnoticed) cases and, for Table 2 , the inclusion of statistics from the war. ${ }^{36}$ In fact, the incidence of non-typhoidal salmonella infections in France was much lower from the 1920 s to the 1950 s than earlier. After the 1950s however, salmonellosis would become

\footnotetext{
${ }^{34}$ Standards at plants: Pietra Santa, op. cit., note 32 above, p. 115. A formal agreement: Proust, op. cit., note 10 above, pp. 203, 207. Minister's comment: Anon., 'De l'importation et de l'inspection', op. cit., note 21 above, pp. 259, 264. Doctors advocating: Colin (d'Alfort) in the discussion following Proust, op. cit., note 10 above, p. 252; Rochaix and Tapernoux, op. cit., note 3 above, p. 8. Gambetta: Gignilliat, op. cit., note 21 above, p. 8. No monitoring abroad: Martel, op. cit., note 25 above, p. 341, 352. Experts assessing: Cassedy, op. cit., note 6 above, p. 13. Treaty of Rome: D Welch, 'From "Euro Beer" to "Newcastle Brown", a review of European Community Action to dismantle divergent “food" laws', J. Common Mark. Stud., 1983, 22: 47-70, on pp. 52-3, 67. Offal: Le Monde, 10 Apr. 2001.
}

\footnotetext{
${ }^{35}$ Salmonellosis: H Bauer, 'Growing problem of salmonellosis in modern society', Medicine, 1973, 52: 323-30, on p. 329. Nineteenth century: Léonard, op. cit., note 8 above, pp. 168-9. Milder in the twentieth century: Sacquépée, op. cit., note 18 above, p. 396; M A Pointeau-Pouliquen, Les causes des intoxications alimentaires en France depuis 1920, Paris, Arnette, 1958, pp. 51, 53; A Névot, 'Intoxications alimentaires d'origine carnée observées dans la région parisienne de 1942 à 1947', Bull. Acad. Méd., 1947, 131: 450-1, on p. 450.

${ }^{36}$ 1949: Pointeau-Pouliquen, op. cit., note 35 above, p. 10; Névot, op. cit., note 35 above, p. 450 . Nineteenth century: Sacquépée, op. cit., note 18 above, p. 385. Twentieth century: J Drucker, 'Épidémiologie des
} 


\section{Making Food Safety an Issue}

Table 3

Causes of food-poisoning, France 1996-7 (Notifications to departmental health services)

\begin{tabular}{lrcccc}
\hline & $\begin{array}{c}\text { No. of } \\
\text { Cases }\end{array}$ & $\begin{array}{c}\text { \% of Total No. } \\
\text { Cases }\end{array}$ & $\begin{array}{c}\text { No. of } \\
\text { Outbreaks }\end{array}$ & $\begin{array}{c}\text { No. of } \\
\text { Deaths }\end{array}$ & \% of Deaths \\
\hline Salmonellae & 4279 & 74.1 & 363 & 5 & 0.1 \\
Staphylococci & 1348 & 23.3 & 66 & 0 & 0 \\
Botulism & 25 & 0.4 & 13 & 0 & 0 \\
Histamine & 121 & 2.1 & 13 & 0 & 0
\end{tabular}

Sources: J Drucker, 'Épidémiologie des maladies infectieuses en France. Maladies surveillées par le Réseau National de Santé Publique. Situation en 1996 et tendances évolutives récentes', Bull. Épidém. Hebdo., Feb. 1998, special issue; S Haeghebaert and colleagues, 'Les toxi-infections alimentaires collectives en France en 1997', Bull. Épidém. Hebdo., 1998, no. 41: 177-81, pp. 1789; J Salomon and colleagues, 'Le botulisme en France en 1997', Bull. Épidém. Hebdo., 1998, no. 44: 201.

the major cause of food-poisoning, perhaps because S. enteritidis spread during the 1960s. During the 1970s, there was much talk about the " $5 f$ 's": faeces, fingers, flies, food, and filth. In France, beef and horse meat were, and still are, major sources of food-poisoningsurpassed only by eggs, owing to the surprisingly high contamination (in some cases, nearly 100 per cent) in poultry farms during the $1950 \mathrm{~s} .{ }^{37}$ From 1993 to 1996 , botulinum was found in hams, ready-made pies and vegetable preserves. But, clearly, the major source of foodpoisoning is the home. Restaurants and cafeterias are inspected more than private houses, and salmonella infections consistently correlate with home-cooked meals. In 1997, homecooking accounted for 71 per cent of all cases of food-poisoning in France. The more pessimistic health authorities become about eradicating salmonella in food, the keener they are to put the responsibility for prevention on households. ${ }^{38}$ And this takes us back to trichinosis.

maladies infectieuses en France. Maladies surveillées par le Réseau National de Santé Publique. Situation en 1996 et tendances évolutives récentes', Bull. Épidém. Hebdo., Feb. 1998, special issue; Pointeau-Pouliquen, op. cit., p. 14; R Legroux, C Jéramec and J-C Levaditi, 'Statistique du botulisme de l'Occupation 1940-1944', Bull. Acad. Méd., 1945, 129: 643-5, on p. 644. Unnoticed cases: Névot, op. cit., p. 450.

${ }^{37}$ Non-typhoidal salmonella: Pointeau-Pouliquen, op. cit., note 35 above, p. 6 . Spread of S. enteritidis: Sacquépée, op. cit., note 18 above, p. 385; Drucker, op. cit., note 36 above, pp. 36-7; and S Haeghebaert and colleagues, 'Les toxi-infections alimentaires collectives en France en 1997', Bull. Épidém. Hebdo., 1998, no. 41: 177-81, p. 178. According to PointeauPouliquen (op. cit., pp. 28, 30), beef from the La Villette slaughterhouses was, in 1924, the origin of a salmonellosis outbreak in a school cafeteria, with more than 200 casualties, some of whom died. Eggs: Anon., 'Réduction du risque de salmonelloses dues aux œufs dans quelques pays d'Europe', Bull. Épidém.
Hebdo., 1997, no. 47: 211; Drucker, op. cit., p. 37; and Haeghebaert, and coll., op. cit., p. 180. The sanitary condition in poultry farms apparently had not improved much by the 1980s: M Biétry, 'Oeufs aux salmonelles: En France aussi ... ', Le Figaro, 11-12 Feb. 1989; and B Werber, 'Salmonelle sans frontières', Le Nouvel Observateur, 8 March 1989. An overuse of antibiotics would later contribute to the development of resistant strains of salmonella: 'Antibiotics on the farm', International Herald Tribune, 10 Jan. 2001. The 5 f's: Bauer, op. cit., note 35 above, p. 329.

${ }^{38}$ According to Bonnain-Moerdijk (op. cit., note 8 above, p. 39), home-made preserves became more common after the First World War. Salmonella in home-cooked meals: Drucker, op. cit., note 36 above, for the 1993-6 period; J Salomon and colleagues, 'Le botulisme en France en 1997', Bull. Épidém. Hebdo., 1998, no. 44: 201. Home-cooking and food-poisoning: Haeghebaert, and coll., op. cit., note 37 above, p. 179. 


\section{Patrick Zylberman}

"War on the enemy [trichinae] is to be waged in the kitchen" was a slogan already well known in 1881. It was hotly debated whether salting and cooking could effectively prevent trichinosis. Full examinations of cured meat were conducted, all of them leading to the conclusion that cooking was the magic bullet against trichinae. As a consequence, hams and, worst of all, the specialty saucisson de Lyon were deemed not 100 per cent safe. Little wonder that trichinosis signalled a national disaster. Those who doubted whether cooking provided adequate protection referred to an "imminent danger". They wanted to reinforce surveillance and boost public awareness, given the lack of scientific studies on the effectiveness of salting and cooking. These proposals were said to represent "patriotic caution", which sounds very much like the "precautionary principle" of our times. ${ }^{39}$

The precautionary principle, it has been said, provides the state with an excuse for not measuring up to international commitments when health risks have political overtones. Precaution is ultimately a matter of sovereignty. In May 1881, the Minister of Agriculture argued in favour of such a principle before the Chamber of Deputies. He wanted to take the precaution of banning meat imports, even though-and perhaps even because-evidence was lacking for making any sound decision. Regarded by contemporaries as legitimate, this ban came along with slogans about preventing foodpoisoning and with measures such as teaching farmers not to feed their pigs rubbish or the guts and blood of recently slaughtered animals. Our forefathers were fully capable of connecting prevention-primarily the concern of individuals-to precautionprincipally the state's responsibility. ${ }^{40}$

American historians have pointed accusingly at European protectionism instead of acknowledging the full import of the disease issue. None of them has mentioned the contaminated American meat arriving from New York in Lyons and Paris. They have, in fact, ruled out the possibility that French or German inspections could have been effective. There is no use denying that protectionism was a powerful motive for banning American ham and bacon. After all, it was not by chance that, three months after the ban, a customs tariff for livestock and meat was issued in May 1881, the first of several tariffs for farm produce adopted by France. Historians have set this issue in the light of protectionism, which was gaining the upper hand on both shores of the Atlantic-we need but recall the 1888-90 McKinley Tariff. After all, meat-packing was a major industry in the United States, and a leading agricultural export at a time when protecting farmers ranked high on the agenda for all governments. American losses subsequent to the European bans soared. American pork exports to Europe dropped from $\$ 70$ million in the early 1880s to $\$ 43$ million in 1890. The German ban alone accounted for \$250 million in losses to US meat-packers between 1883 and 1891. Having started as a public health issue, the pork ban

\footnotetext{
${ }^{39}$ Laborde, op. cit., note 18 above, p. 176. Although cooking was generally accepted as an effective means of sterilization (Rochaix and Tapernoux, op. cit., note 3 above, p. 19), it was rather difficult at the time for home-made dishes to meet requirements. Ham, for instance, has to reach an internal temperature of $100^{\circ} \mathrm{C}$.
}

\footnotetext{
${ }^{40}$ State excuse: F Ewald, 'La précaution, une responsabilité d'État', Le Monde, 11 March 2000 Chamber of Deputies: Anon., 'De l'importation et de l'inspection', note 21 above, p. 193. Prohibition as precaution: ibid., p. 262; P Bert to the Société de Médecine Publique in Proust, op. cit., note 10 above, p. 199. Teaching farmers: ibid., p. 200.
} 


\section{Making Food Safety an Issue}

ended up becoming a matter of protection. Paris lifted the ban at the same time that it promulgated a 25 franc tariff, in October $1891 .^{41}$

None the less, we can make a good case for the argument that public health was at stake. Like other European countries, France lifted its ban when the US Congress passed the 1890-1 meat inspection laws. From the start, American ambassadors in Europe had argued that official inspections were the only way to end the dispute. It has been rightly said that "the American pork boycott exemplifies both economic nationalism and the American government's reluctance to assume responsibility for public health". Furthermore, there is no question that the exposure by US investigators in 1880 of the "filthy conditions" in the Chicago stockyards cast American exports into disrepute. In July 1881, the French parliament passed the first law regulating animals and animal products; and in November, an autonomous Ministry of Agriculture was set up with a veterinary division. In parallel, the US Congress created in 1884 a Bureau of Animal Industry in the Department of Agriculture, which achieved cabinet rank only in 1889. Ultimately, as had happened during the rinderpest epidemic, disease was associated with food imports and thus became a central issue; it served as the pretext for the Federal government's first interventions in food quality. During the pork dispute, this issue related not just to the "high politics" of an international trade war but also to the problem of effective customs services, border controls and inspection techniques using microscopes. ${ }^{42}$

Following the introduction of refrigeration around 1880, the conditions of competition changed in the American meat industry. Parallel to this shift in technology, sanitary issues were upgraded to become a matter to be handled through diplomacy. Awareness was growing of the need to control disease and take preventive action. Given advances in microbiology and the revolution in transportation, disease had to be seen in the context of a vast "biological community" comprising entire nations or even spanning oceans. The US Secretary of State asked the American ambassador to France to inquire into the pork ban upon his arrival in France (in 1889). Not only agriculture ministers but also ministries of foreign affairs and ambassadors were caught up in the dispute. From the start, negotiations took place at the inter-governmental level. Representatives of several foreign governments paid close attention to the new inspection procedures implemented under the 1891 Meat

\footnotetext{
${ }^{41}$ American historians: L L Snyder, 'The American-German pork dispute 1879-1891', J. mod. Hist., 1945, 17: 16-28; Duncan, op. cit., note 21 above, p. 195; Gignilliat, op. cit., note 21 above, p. 4; Cassedy, op. cit., note 6 above, p. 15; and G D Libecap, 'The rise of the Chicago meat-packers and the origins of meat inspection and antitrust', Econ. Inq., 1992, 30: 242-62 on p. 250-2. As for German historians, see: Hoy and Nugent, op. cit., note 22 above, p. 200. Meat-packing, a major industry: Libecap, op. cit., p. 246; Gignilliat, op. cit., p. 3. American pork exports: Hoy and Nugent, op. cit., pp. 216, 221. To this should be added the cost of controls imposed on American cattle or due to the British Cattle Diseases Act of 1878. See Libecap, op. cit., pp. 251-2. Lifted ban: Duncan, op. cit., p. 195.
}

\footnotetext{
${ }^{42}$ Economic nationalism and filthy conditions: Gignilliat, op. cit., note 21 above, pp. 12 and 11 respectively. France: Désert and Specklin, op. cit., note 10 above, pp. 386-7, 390-1; Léonard, op. cit., note 8 above, pp. 170-1. Bureau of Animal Industry: Hoy and Nugent, op. cit., note 22 above, p. 213; Gignilliat, op. cit., p. 10. Federal interventionism: Hoy and Nugent, op. cit., p. 214; Libecap, op. cit., note 41 above, p. 255. Cassedy, op. cit., note 6 above, pp. $9,15,14$. In 1938 doubt still surrounded French protective measures against trichinosis. Microscopic examinations of tissue were still not being systematically performed at the end of the 1930s, according to Rochaix and Tapernoux, op. cit., note 3 above, p. 18 .
} 


\section{Patrick Zylberman}

Inspection Law in the United States. The mixture of "technical" and "high foreign" politics is not an invention of our own times. Like the "shock" of the cattle plague in the 1870s, the pork dispute provided a stimulus to animal health and scientific internationalism in the New as well as the Old World. ${ }^{43}$

In the end, two main factors apparently account for the long-standing obstacles to the establishment of general international regulations about food safety. On the one hand, the precautionary principle remained in the background for a long time because, by nature, food is a "politically emotive area". ${ }^{44}$ On the other, the inadequacy or ineffectiveness of national meat inspections undoubtedly kept countries from approving common standards.

\section{III}

"One can't imagine what people used to eat in Troyes before 1885", wrote Emmanuel Leclainche, who was earning his living as a veterinarian in Champagne during the last decades of the nineteenth century and later became the first president of the World Organisation for Animal Health (created in 1924). Urbanization was forcing more and more people to depend on shop-bought food; and new techniques in chemistry were endangering the food supply, being used to adulterate food. Paul Lafargue aptly put it, "Our time will be called the age of falsification". In Brussels, saucissons dits de Bologne were made from the meat of horses that were sick or had died of contagious disease. This did not upset people. A French butcher replied to an angry mayor, "You don't need to worry about the health of our fellow citizens, Sir, for I am selling unwholesome meat only to the troops" ! ${ }^{45}$

Hygiene was appalling, not only in shops but in factories as well. How could things have been any different? In spite of the British Food and Drugs Acts of 1872 and 1875 (the latter remained the basis of food law in the United Kingdom until 1955), controls in Britain were poorly conducted because neither central nor local authorities were keen to enforce them. The German "Law on Dealings, Food, and Utensils" of 14 May 1879 actually reinforced controls, but regional differences in effectiveness remained until the turn of the century. ${ }^{46}$ Contemporaries regarded France's 1905 Food Adulteration Act as a public health measure. It incorporated past laws such as those of

\footnotetext{
${ }^{43}$ Biological community: Hoy and Nugent, op. cit., note 22 above, p. 214. American ambassador to France: Duncan, op. cit., note 21 above, p. 190; Gignilliat, op. cit., note 21 above, p. 12. Foreign representatives, scientific internationalism: Cassedy, op. cit., note 6 above, pp. 7 note $6,11-12$.

${ }^{44}$ Welch, op. cit., note 34 above, p. 57.

${ }^{45}$ Troyes: E Leclainche, Le Petit Républicain de l'Aube, 17 July 1888, in C Morot, 'La viande, son inspection et ses inspecteurs', Ann. Hyg., 1893, 3s, 29: $118-44$, on p. 122. Urbanization and new techniques: Teuteberg, op. cit., note 2 above, pp. 146-7. Lafargue: Léonard, op. cit., note 8 above, p. 187. Saucissons dits de Bologne: Morot, op. cit., pp. 118-19. Butcher: ibid., pp. 133-4. Hygiene in factories: Société Universelle de la Croix-Blanche de Genève, Deuxième congrès international pour la répression
}

des fraudes concernant les denrées alimentaires, Paris 17-24 Oct., Paris, Secrétariat Général, 1909, p. 1001.

${ }^{46}$ Britain: R A Robinson, 'Food adulteration in England and France', Trans. Med.-Leg. Soc., 1909-10, 7: 51-68, on p. 51; A S Wohl, Endangered lives: public health in Victorian Britain, Cambridge, MA, Harvard University Press, 1983, p. 54; French and Phillips, op. cit., note 8 above, pp. 1, 47. Germany: Teuteberg, op. cit., note 2 above,

pp. 151-4; and R Abel, 'Ueber die Bedürfnisse der Nahrungsmittelgesetzgebung', in Bericht über den XIV Internationalen Kongress $f$. Hygiene und Demographie, Berlin, 23-29 Sept. 1907, Band II, Berlin, A Hirschwald, 1908, pp. 298-305, on pp. 299-301. 


\section{Making Food Safety an Issue}

27 March 1851 and 5 May 1855 against fraud, whether detrimental to health or not, in food and drink (mainly wine). Another act (of 23 June 1857) punished fraud and foodpoisoning but without providing for controls. Before 1905, France lacked laboratories for running tests: meat was not legally normalized, and butcheries were not inspected. There was a need for monitoring the food-processing industry, in particular small family businesses, where conditions were described as extremely insanitary. Besides regulating sampling procedures and methods through the 1905 law, the Ministry of Agriculture gained full authority over food hygiene, thanks to market inspectors, veterinarians and customs agents (in all, 1 per 50,000 inhabitants) as well as public laboratories (only 27 in 1907). In the opinion of British hygienists, this centralization helped put teeth into the 1905 act. $^{47}$

Hygienists were not so blind as not to see that the 1905 act mainly advanced the principle of "commercial probity", whereby authorities might enforce regulations requiring products to bear labels indicating ingredients and origins. Throughout the nineteenth century, consumers had often lodged complaints about the absence of labels. Thirty-five years after its passage, the Food Adulteration Act would be rather negatively assessed: it had made markets, not health, more salubrious. Food could be inspected only in the marketplace, since provisions for controls at manufactories were lacking. ${ }^{48}$ The Ministry of Agriculture was responsible for running tests on foodstuffs, although a short list of food colours and additives could be tested by the Ministries of Public Health and Agriculture. Since it mainly aimed at improving business practices, the 1905 act would later be incorporated in the Consumer Code, not the Public Health Code. In line with the 1902 public health law that made mayors responsible for "honesty in transactions and cleanliness in marketed food", it was first and foremost an administrative police measure; public health was a secondary concern. As we shall see, much the same would happen to EU legislation, which, from the start,

\footnotetext{
${ }^{47} 1905$ act as public health law: A Chassevant, 'État actuel de la législation concernant les aliments et la surveillance des aliments dans les différents pays (étude spéciale de cette législation en France)', Hyg. Géné. Appliq., 1907, 2: 542-50, on p. 544; O’Neill, op. cit., note 23 above, p. 564; Robinson, op. cit., note 46 above, pp. 52, 55. Past regulations: A Rochaix, J Courmont and C Lesieur, Précis d'Hygiène, Paris, Masson, 1940, p. 262; A Chassevant, 'Rapport sur l'état actuel de la législation concernant les aliments et la surveillance des aliments dans les divers pays', in Bericht über den XIV Internationalen Kongress $f$. Hygiene und Demographie, Berlin, 23-29 Sept. 1907. Band II, Berlin, A Hirschwald, 1908, pp. 251-6, on p. 254. The butter and margarine law of 16 April 1897 was also taken up in the 1905 Act. Without providing for controls: Dr Hogg, 'Organisation de l'inspection des substances alimentaires', Ann. Hyg., 1881, 3s., 5: 526-35, on pp. 527-8. Pre-1905: Ellis, op. cit., note 21 above, p. 197. Regulating sampling: Chassevant, 'Etat actuel de la législation', op. cit., pp. 547-9. Administrative services: Chassevant, 'Rapport', op. cit., p. 255. Section 3 of
}

France's Superior Council of Public Hygiene, the main consultative body in public health, focused on food hygiene. Centralization: O'Neill, op. cit., p. 564; Robinson, op. cit., p. 63.

${ }^{48}$ Commercial probity: Chassevant, 'Rapport', op. cit., note 47 above, p. 253. Complaints: G Thuillier, Pour une histoire du quotidien au XIX $X^{e}$ siècle en Nivernais, Paris, Mouton, 1977, p. 151 notes 59 and 60. Markets not health: Rochaix, and coll., op. cit., note 47 above, p. 263. Turning scientific knowledge into a means for effectively protecting consumers took time. Control of the quality of oysters, for instance, went into effect in 1924 - after more than two decades of warnings by: Chantemesse in 1896, Mosny in 1899 and Netter in 1907. In fact, it was not public authorities but producers themselves who would, in 1913, set up the first system for inspecting oysters. About this, see Rochaix and Tapernoux, op. cit., note 3 above, pp. 25-8. Control at factories is of rather recent date: N Zylbermann, 'L'organisation de la sécurité alimentaire en France', Actualités, concurrence, consommation et répression des fraudes, Sept. 1998, CXIII, suppl., pp. 1-2. 


\section{Patrick Zylberman}

combined measures against food adulteration and for food safety but with major emphasis on the first. ${ }^{49}$

Interestingly enough, France modelled its regulations on proposals emanating from several international congresses. ${ }^{50}$ As a consequence of international hygiene congresses in 1878, 1882 and 1887, Paul Brouardel, ${ }^{51}$ along with Bouley and others, called for national as well as international regulations. In Europe and the United States, chemists joined the ranks of those asking for inspections. At the second Congress of Applied Chemistry, held in Paris in 1896, an international codex was proposed for coupling trade with hygiene. ${ }^{52}$ Successive conferences would take up this proposal with hardly any change in its wording. Belgium played an instrumental role in this process. Also important were non-governmental initiatives, such as the two meetings on food adulteration held in Geneva and Paris under the auspices of the Swiss-based CroixBlanche in 1908-9. ${ }^{53}$

\footnotetext{
${ }^{49}$ Short list: Archives Nationales (hereafter AN), 880495 art. 4, Comité de la Santé Publique du Traité de Bruxelles, [Prof. A Névot] 'Rapport relatif au contrôle des denrées alimentaires en France', 30 July 1952. Business practices: ibid. Under the heading "deceit and attempted deceit of the public", the 1905 act has become art. L 213-1 ff. of the Code de la consommation. Food hygiene is currently regulated through a 26 April 1991 decree (Journal Officiel, 4 May 1991), Annexe 1 of the Code de la santé publique. Food and the 1902 act: Chassevant, 'Rapport', op. cit., note 47 above, p. 252. Public health secondary: Anon., 'Le $1^{\text {er }}$ Congrès international pour la répression des fraudes alimentaires et pharmaceutiques', Hyg. Viande Lait, 1908, 2: 461-75, on p. 471. EU legislation: Welch, op. cit., note 34 above, pp. 49-50; AN 880495 art. 4, Comité de Santé Publique du Traité de Bruxelles, sous-comité d'experts sur le contrôle sanitaire des denrées alimentaires, 'Observations françaises sur le rapport collectif néerlandais relatif aux antiseptiques', 25 Aug. 1954.

${ }^{50}$ Modelling of regulations: Chassevant, 'Etat actuel de la législation', op. cit., note 47 above, p. 550; L Grosz de Csatàr, 'L'influence des mesures internationales pour maintenir la bonne qualité des boissons et des aliments', Trans. Intern. Med. Cong., 7th session, London, 2 to 9 Aug., London, J W Kolckmann, 1881, vol. 4.

${ }^{51}$ Paul Brouardel (1837-1906) occupied the chair of pathology at the Paris Medical School in 1879, of which he became dean (1887-1901). He was a member of the National Academy of Medicine (1880), chaired the General Association of French Physicians (1902-6), and presided over the Consultative Committee (later: Superior Council) of Public Hygiene (1884-1904). Brouardel in 1882:

F Bordas, 'L'unification des méthodes d'analyse des produits alimentaires', Rev. Scient., 1913, 51: 526-9,
}

on p. 526. Brouardel in 1887: A Chassevant, 'Unification des méthodes d'analyse des denrées alimentaires dans les laboratoires officiels, en vue de la détermination et de la répression des falsifications', Bull. Sci. Pharmacol., 1906, 13: 675-8, on pp. 675-6.

${ }^{52}$ Chemists: Bordas, op. cit., note 51 above, p. 527. The Food Section of the International Congress of Applied Chemistry wanted to see an international network established for sharing scientific data (Chassevant, op. cit., note 51 above, p. 676), and the 9th Section of the Second Congress asked for food standards to be implemented: F Dupont (ed.), $2^{e}$ Congrès international de chimie appliquée, Paris, Association des Chimistes de Sucrerie et de Distillerie, 1897, vol. 4, p. 350. Incipient internationalization: A Chassevant, 'Le congrès international pour la répression des fraudes alimentaires et pharmaceutiques, impressions générales', Hyg. Géné. Appliq., 1908, 3: 577-82, on pp. 577-8; Bordas, op. cit., p. 527; D F Smith and J Phillips, 'Food policy and regulation: a multiplicity of actors and experts', in Smith and Phillips (eds), op. cit., note 8 above, pp. 1-16, on p. 5. Dr N Wright (chief scientific adviser to the Ministry of Agriculture, Fisheries and Food in the 1950s) wrongly stated that the idea of a Codex Alimentarius was launched at the first conference, held in Brussels in 1894: N Wright, 'International aspects of pure food and pure food legislation', in A J Amos, Pure food and pure food legislation, papers of the 1960 Centenary Conference, London, Butterworths, 1960, pp. 73-106, on p. 80. In truth, three Austrian physicians introduced a proposal for a Codex Austriacus, but it was left undiscussed: F Sachs (ed.), $1^{\text {er }}$ Congrès international de chimie appliquée, Brussels, G Deprez, 1894, 7 Aug. session, p. cliv.

${ }^{53}$ Wording hardly changed: C Franche, 'Les falsifications au Mexique et le contrôle chimique 


\section{Making Food Safety an Issue}

Some pundits resented France's influence in these various international meetings. Joseph Ruau, French Minister of Agriculture (and author of the 1905 act) declared at the 1909 Paris meeting that honesty in business, hygiene, and international cooperation could be harmoniously linked. He thought all this should become part of a Codex Alimentarius. This did not mean that border controls (poorly organized in France at the time) were not worthwhile: after all, such a harmonization was far from being realized. Ruau was not alone in holding this opinion. ${ }^{54}$

Between the wars, the whole process stalled midstream, even though France and Germany speeded up administrative reforms. Public authorities were still preoccupied with the usual topics of food hygiene, such as inspecting oysters, milk or industrial bread (pain chimique). Doctors increasingly called for food to be checked while it was being made, not just when it was marketed. Britain, Germany, and Denmark-but not France-managed to enforce measures of this sort, at least on milk. At international meetings however, nutrition rather than food control was coming to the forefront. Food safety was still discussed in terms of the same methods and goals as previously, namely a call for uniform international standards and techniques. 55

As a matter of fact, food-poisoning would attract more attention from international organizations following the Second World War. In 1953, the Sixth World Health Assembly called for study of the "new public health problem" caused by a growing use of food additives. In January of the following year, the WHO Executive Committee suggested that the Joint FAO/WHO Committee of Nutrition Experts (created in 1949) should examine the technical and legal questions related to food additives. Meeting in October and November, this committee drew attention to wide divergences in national laws and deplored the lack of knowledge about the health risks of additives. The WHO proposed organizing a joint conference with the FAO, which governments, intergovernmental agencies and non-governmental organizations attended. It proposed setting

international de Mexico', Rev. Intern. Falsif., 1905, 18: 163-5, on p. 164; Chassevant, 'Etat actuel de la législation', op. cit., note 47 above, p. 544; idem, op. cit., note 51 above, p. 577; Croix-Blanche, op. cit. note 45 above, p. 56; Wright, op. cit., note 52 above, p. 74; FAO/66479, Joint FAO/WHO Codex

Alimentarius Commission, 'Report of the First Session', Rome, 25 June-3 July 1963, p. 53; J P Dobbert, 'Le Codex Alimentarius: vers une nouvelle méthode de réglementation internationale', Ann. Franç. Droit Intern., 1969: 677-717, pp. 680, 693.

Belgium: Chassevant, op. cit., note 51 above, p. 676; idem, 'Rapport', op. cit., note 47 above, p. 256;

Bordas, op. cit., note 51 above, p. 527. Croix-Blanche, op. cit., p. 60.

${ }^{54}$ France resented: Chassevant, op. cit., note 52 above, p. 580. Ruau 1909: Croix-Blanche, op. cit., note 45 above, p. 57. Codex: Croix-Blanche, ibid., p. 58. Poorly organized border inspections: Martel, op. cit., note 13 above, p. 397. Worthwhile: Croix-Blanche, op. cit., p. 59. Far from realized: Croix-Blanche, ibid., p. 58. Not the only one: Bordas, op. cit., note 51 above, p. 528.

\footnotetext{
${ }^{55}$ Administrative reforms in Germany: Teuteberg, op. cit., note 2 above, p. 155 . Usual topics of food hygiene: J Parisot, 'État du problème de l'alimentation rationnelle en France', in L Viborel (ed.), Savoir prévenir, Paris, L Viborel, 1939, pp. 59-75, on pp. 72, 64. Control at production: Rochaix and Tapernoux, op. cit., note 3 above, p. 3 . Rochaix (op. cit., note 47 above, p. 145) cites examples of milk control laws: Great Britain's 1926 Milk and Dairies Order and 1936 Milk Special Designations Order, Germany's legislation of 31 July 1930, Denmark's act of 22 October 1925. In France, the 7 July 1933 Law on Meat, Milk and Bovine Tuberculosis (implemented by a decree of 24 January 1934) and the 2 July 1935 Act on Dairies and Pasteurisation of Milk did not lead to decisive action. Nutrition rather than food control: Parisot, op. cit., p. 63. Call for uniform standards: League of Nations, A/59/1936/II/B, $\mathrm{H}$ Queuille, 'Alimentation, rapport présenté par la deuxième commission à l'Assemblée', Genève, 5 Oct. 1936, p. 3.
} 


\section{Patrick Zylberman}

up a joint expert committee that "would attempt to lay down acceptable broad general principles governing the use of food additives". This conference, chaired by Dr Norman Wright, took place in Geneva on 19-22 September 1955. To achieve "uniformity in the general principles on which legislation is based", it concentrated on a set of basic principles and methods for regulating the use of additives and assessing their safety instead of focusing on a so-called "positive" list of authorized food colours to which the British, in particular, were hostile. In fact, future meetings would have to overcome Britain's strong objections, and this may well have had an effect on the formation of a set of general principles. ${ }^{56}$

This theme of "general principles" runs through a meeting organized in Bad Godesberg by the Deutsche Forschungsgemeinschaft in May 1954. Prof. René Truhaut, a toxicologist from the Paris Faculty of Pharmacy, constructed a set of general principles (adopted for antiseptics as well) at this meeting. Other conferences on food colouring and additives would meet in Vienna (1955), Amsterdam (1956) and Como (1957) under the auspices of the International Committee of Agriculture Industries, the Permanent International Bureau of Analytical Chemistry and the Brussels Pact Food Regulation Working Party. The Bad Godesberg meeting called for the mandatory labelling of food additives. More importantly, it was the first conference that advocated "general principles", for example, that prescriptions should be legally regulated, that the public should not be deceived, that products should have no harmful effects on human health and should be added to foodstuffs only if necessary, and that permissable levels of food colouring should be set. The idea itself of general principles was approved at the São Paulo meeting of the International Union for the Prevention of Cancer (July 1954) and at the fifth meeting of the Brussels Pact Food Regulation Working Party in Luxembourg (October 1954). The São Paulo conference deemed it a "solid general basis for providing guidance" in matters of food additives and colours. These principles would form the bedrock of European and national legal regulations about food safety and hygiene. ${ }^{57}$

\footnotetext{
${ }^{56}$ FAO/59911, Joint FAO/WHO Conference on Food Additives, 'Report', Geneva 19-22 Sept. 1956, pp. 3-4. That little was known about food additives in 1953 sounds odd, since food colouring and additives had often come to the attention of medical congresses. For France, see P Brouardel, 'Accidents causés par l'addition des antiseptiques aux aliments', Ann. Hyg. Pub., 1903, 49: 420-44; and A Chassevant, 'Colorants dont l'emploi peut être autorisé pour la fabrication des produits alimentaires', Hyg. Géné. Appliq., 1910, 5: 321-33. About this question in general, see Koolmees, op. cit., note 9 above, p. 62. British objections: FAO, op. cit.,p. 5; AN 880495 art. 4, René Truhaut in Brussels Treaty Organisation, doc. no. A/2410, 19 Oct. 1954, 'Rapport de la $5^{\mathrm{e}}$ Réunion du sous-comité pour le contrôle des denrées alimentaires', Luxembourg, 6-8 Oct. 1954. Signed in March 1948 by the United Kingdom, France, Belgium, Luxembourg and the Netherlands, the Brussels Pact would be renamed the Western European Union in October 1954 when Germany and Italy joined. Though focused on regional security, this pact had a much wider scope. It set up a
}

Food Regulation Working Party for handling the issue of food colours and additives.

${ }^{57}$ Mandatory labels: AN 880495 art. 4, L Truffert, 'Rapport sur le $1^{\text {er }}$ Symposium sur les matières étrangères et éléments synergiques dans les aliments', Vienna, 6-9 July 1955; M G Périer de Féral, 'Comment comprendre la déclaration des substances étrangères dans les aliments', in Commission Internationale des Industries Agricoles (Paris) and Bureau International Permanent de Chimie Analytique (Paris) (eds), $3^{e}$ Symposium sur les substances étrangères dans les aliments, Como, 14-18 May 1957, Milano, Unione Tipografica, 1958, pp. 392-405, on p. 393. Brussels Pact: See AN 880495 art. 4, Minister of Public Health to Prof. A Névot, Direction générale de l'Hygiène publique et des Hôpitaux/Direction de l'Hygiène publique/3, 19650, 1 Feb. 1950; Brussels Treaty Organisation, op. cit., note 56 above, 19 Oct. 1954; and Truffert, op. cit. Major change: AN 880495 art. 8, Ministre de l'Agriculture au Ministre de la Santé Publique et de la Population, AR-C 83134, 18 May 1961. 


\section{Making Food Safety an Issue}

The call for uniform technical standards advanced faster than legislation. Put on the table for the first time in the late nineteenth century (see above) the idea of an international code resurfaced at the 1955 Vienna conference. Three years later, a Permanent Council of the Codex Alimentarius-an old ambition-was set up with nineteen governments represented. Two regions stood in the forefront: Latin America, where a chemistry congress in 1924 had proposed drawing up a Codex Alimentarius Sudamericanus, and Europe. A new Joint WHO/FAO Conference on Food Standards was held in Geneva in October 1962..$^{58}$

The Joint FAO/WHO Codex Alimentarius Commission organized its first meeting in Rome in June 1963: thirty countries and sixteen international organizations attended. The 1962 Food Standards Conference in Geneva had set the objectives: to centralize the drawing up of standards and then promote regionally based discussions. As can be seen by examining the history of the UN Protein Advisory Group, nutritionists were, at the time, gaining the upper hand over UN policy-making in public health. In 1998, 104 countries and sixty-three international organizations attended the twenty-third Codex meeting. ${ }^{59}$

As a matter of fact, before the EEC intervened in the food realm, the Codex meetings provided a forum where opinions could be voiced by experts from many inter-governmental structures (the OEEC, the Brussels Pact, etc.) removed from the main West European agricultural trade meetings, such as the 1953-55 Green Pool conferences. Both the Joint FAO/WHO Milk Committee and the European Section of the 1958 Permanent Council of the Codex Alimentarius became organs of the new Codex Commission. The latter was empowered to lay down the general principles for the contents of the Codex Alimentarius and the procedures to be used by it. Its draft proposal was referred to a Committee on General Principles chaired from the start by the French delegate. ${ }^{60}$

As seen in the drafting of the Codex Alimentarius, health and trade have never been on equal footing. The Netherlands, Germany, Sweden, Switzerland, Italy and Austria supported uniform standards as a way to ease trade barriers rather than to protect public health-even though all these countries would adopt a contrary position during the 1996 "mad cow crisis". Spain was in the opposite camp; France, in the middle. The dominance of trade over public health was undoubtedly reinforced by the nature of expertise at the time. From the very start, the food industry exercised influence over the

\footnotetext{
${ }^{58}$ Technical standards advanced faster: Wright, op. cit., note 52 above, p. 77. Vienna: ibid., p. 80 . Old request: Bordas, op. cit., note 51 above, p. 528. Permanent Codex Council: Wright, op. cit., p. 80. Two regions: ibid., p. 81. Geneva October 1962: FAO/ 59911, op. cit., note 56 above, p. 4.

${ }^{59}$ Protein Advisory Group: J Ruxin, 'The United Nations Protein Advisory Group', in Smith and Phillips (eds), op. cit., note 8 above, pp. 151-5. Thirty countries: FAO/59911, op. cit., note 56 above, p. 4. Objectives: FAO, ibid., p. 6. OEEC:

A S Milward, The European rescue of the nation-state, Berkeley, University of California Press, 1992, pp. 286-7, 301. Codex meeting 1998: Direction
}

\author{
Générale de la Concurrence, de la Consommation et \\ de la Répression des Fraudes (hereafter DGCCRF), \\ Rapport d'activité: Qualité et sécurité, 1999, \\ www.finances.gouv.fr/DGCCRF. \\ ${ }^{60}$ Green Pool conferences: Milward, note 59 above, \\ pp. 301-8. General Principles Committee: Dobbert, \\ op. cit., note 53 above, p. 685 . France chaired the \\ Committee again in 1998 when discussions revolved \\ around the issue of "legitimate factors other [than \\ science]": DGCCRF, Rapport d'activité, 1998, \\ www.finances.gouv.fr/DGCCRF. The European \\ Council of the Codex Alimentarius was later \\ renamed the Advisory Group for Europe of the Joint \\ FAO/WHO Codex Alimentarius Commission.
}




\section{Patrick Zylberman}

drafting and implementing of food safety standards. As Smith and Phillips have pointed out, industrialists were not averse to assuming the role of expert; and their opinions seemed to carry more weight than those of the experts. ${ }^{61}$ To cite one national example: in the early 1970s, the decision was made to increase the number of industry representatives from three to six on the French Ministry of Agriculture's Standing Commission on Animal Feed. Although some recommendations made by this commission had a serious impact on human health, the Minister nearly forgot to appoint the director of the National Institute for Medical Research to this commission. ${ }^{62}$ And to complete this with an international example: 80 per cent of non-governmental participants at the Codex meetings in the 1990s came from industry and 1 per cent from non-profit organizations.

The International Chemistry Union, the Permanent International Committee on Canned Food, the International Transport Union, the Phytopharmaceutical International Congress, etc., were all trying to come to grips with food safety-not to mention the International Union against Cancer and the European Federation of Zootechnics. Many of these organizations took part in the 1962 Geneva Food Standards Conference. In contrast, scientific experts (toxicologists and physicians) were active on an ad hoc basis; and careful efforts were made to avoid directly associating them with programme-and-policy committees. At the 1955 Geneva conference, the suggestion had been made to call on independent experts serving in a personal capacity and not as national representatives. Interestingly enough, the same suggestion came up again when the European Commission reformed its scientific committees in 1997. This reminds us of the method used by the Health Section of the League of Nations, with a difference: the aim was less to "denationalize" expertise than to limit the role of scientific experts as sources of information. ${ }^{63}$

The EEC's Food Regulation Working Party which came into operation in the 1960s provides another case in point. This Working Party let agro-industry representatives play a leading role and even praised them for their "close, uninterrupted collaboration". These representatives were not just asked for written and oral opinions but were actually assigned the task of conducting preliminary studies with a view to harmonizing European food safety regulations. The harmonization of jam-making standards provided an occasion where industry representatives could "serve for inter-governmental discussions"- after all, Jean Monnet had toyed with the idea of having farm

\footnotetext{
${ }^{61}$ Health and trade: FAO/59911, op. cit., note 56 above, Appendix E1. Mad cow crisis: C Goethals, S C Ratzan, V Demko, 'The politics of BSE: negotiating the public's health', in S C Ratzan (ed.), The mad cow crisis: health and the public good, London, UCL Press, 1998, pp. 95-110, on pp. 99-100, 102. Smith and Phillips, op. cit., note 52 above, p. 6.

${ }^{62}$ AN 880495 art. 4, [Dr A Caillet], 'Note pour Monsieur Boyon, conseiller technique', DGS/HP/2, n.d. [late 1972-early 1973]; Dr Charbonneau [A Caillet], 'Note pour Monsieur le Ministre', DGS/HP/2, 6 Oct. 1972; J Foyer, Ministre de la Santé Publique au Ministre de l'Agriculture, 27 Nov. 1972; Ministre de la Santé Publique au Ministre de
}

l'Agriculture, DGS/1722, 13 Aug. 1972. The Commission on Animal Feed was created by the Minister of Health in 1956 (arrêté of 5 May and Journal Officiel of 25 May), recreated jointly by the Ministers of Health and Agriculture in 1960 (arrêté 22 February, J.O., 12 March). It was modified on 20 January 1967 (J.O., 14 February), and again on 1 February 1973 (J.O., 23 March).

${ }^{63}$ This "dual structure" inevitably developed in European Union committees of experts:

G P E Walzenbach, 'Convergent co-ordination patterns in the French and German core executive: The case of the BSE crisis', West Eur. Polit., 1999, 22: 64-86, on p. 73. 


\section{Making Food Safety an Issue}

organizations conduct agricultural policy and set standards regulating quality as well as quantity. Indeed, this was the usual procedure in matters of food safety. In March and April 1961, a Code of Principles concerning Milk and Milk Products was issued that set minimum standards for ingredients and for methods of sampling and analysis. It had been jointly conceived by the FAO and the International Dairy Federation. ${ }^{64}$

Policy committees on food safety clearly thought that independent experts should play a minor, even subservient, role. In the 1950s, the lack of nutritionists in some countries, such as France and probably also the Netherlands, may partly explain this situation, along with strong objections to "food dirigisme", which the French public rejected given its experience of rationing during and just after the Second World War. ${ }^{65}$

Even as the food industry was becoming ever more deeply entrenched in national as well as international institutions, experts were ever more divided into two unequally influential categories. In 1965, the chairman of the French Association of Animal Food Additive Industries opposed, with some success, the Academy of Medicine on the issue of antibiotics in cattle feed. To the daily L'Aurore, he smugly declared that the Ministry of Agriculture's Commission on Animal Feed, of which he was also a member, was "strictly protecting health and firmly enforcing regulations over cattlebreeding and animal products used in human food". This rampant abuse of advisory committees, where government officials sided with industry representatives, is proof of how under-represented and weak the Ministry of Health was on such committees, apart from those dealing with food additives. As the director of the Minister of Agriculture's cabinet would later explain, food safety depended on an industry that imposed its own discipline under the control of a technical committee on which a significant number of industry representatives sat: "With no [legal] sanctions whatever, and relying entirely on the free adhesion of corporations, this method seems rather insubstantial". It was so insubstantial that it angered the Ministry of Health; even officials in the Agriculture Department started grumbling. ${ }^{66}$

Balancing out the interests of trade (or farming) and health was going to take a long time. A tentative solution took the form of the WTO Agreement on the Application of

\footnotetext{
${ }^{64}$ EEC Food Regulation Working Party: AN 880495 art. 4, Dr Lacambre, 'Note pour Monsieur le Ministre, Coopération économique européenne', DGS/HP 102S, account of the meeting of the Subcommittee of Food Regulation in Brussels on 5-7 Oct. 1960; and AN 880495 art. 8, Dr Lacambre, 'Note pour Monsieur le Ministre, Coopération économique européenne', DGS/HP 25S, 21 Feb. 1961. Industry collaboration on jam: Dr Lacambre, ibid. Monnet: Milward, op. cit., note 59 above, p. 284. Usual procedure: Truffert, 'Rapport', 6-9 July 1955, op. cit., note 57 above. Milk: FAO/59672, Joint FAO/WHO Experts Committee, 'Code of principles concerning milk and milk products', in WHO/FAO, Milk Hygiene, 1962, Annex 1, preamble, pp. 747-50, on p. 747; Wright, op. cit., note 52 above, p. 84. Milk had been standardized at the 1908 Conference on Food Adulteration in Geneva: Rochaix and Tapernoux, op. cit., note 3 above, p. 28. In France,
}

a 25 March 1924 decree set standards for the milk industry.

${ }^{65}$ Lack of nutritionists, food dirigisme: AN 880495 art. 4: Dr Marcheboeuf, 'Compte-rendu de mission de la délégation française à la $2^{\mathrm{e}}$ Conférence de la Nutrition en Amérique latine, Rio de Janeiro 5-13 juin 1950', Aug. 1950.

${ }^{66}$ Antibiotics: A Nordon, 'Les antibiotiques ajoutés à la nourriture du bétail ne sont pas un danger pour l'homme', L'Aurore, 2 Apr. 1965. Underrepresentation of Ministry of Health: Dr Lacambre, 5-7 Oct. 1960, op. cit., note 64 above; AN 880495 art. 4: Ministre de la Santé publique au Ministre de l'Agriculture, 13 Aug. 1972; Dr Charbonneau, 'Note pour Monsieur le Ministre', DGS/HP/2, 26 July 1972; Ministre de 1'Agriculture [E Duchêne-Marullaz, director of the cabinet] to the Ministre de la Santé publique, RF-R1 84364, 4 Aug. 1972 and to the vicechairman of the Conseil d'État, RF-A1 81583, 1 March 1973. 


\section{Patrick Zylberman}

Sanitary and Phytosanitary Measures of 15 April 1994. This so-called SPS Agreement is often said to mark a turning point in the diplomacy of food safety. Although the Codex had initially been intended as a set of regulations for achieving international consensus without recourse to formal agreements, the SPS treaty (operative from 1 January 1995) requires that governments design food safety policy in line with Codex standards. Accordingly, international standards-once adopted by the Codex Commission and thus before being formally accepted by the signatory state-prevail over national governments' decisions. Science is central to the whole procedure. To adopt a higher level of protection than the international standard, a state has to produce sound scientific evidence. In fact, EEC working groups had been following this procedure from the start. ${ }^{67}$ In this respect, the SPS treaty was the crowning achievement of an era when science reigned supreme. It thus seems to mark the end of an era rather than a new beginning.

\section{IV}

This new scientific order soon came into question. Although the EEC had started taking food policy under consideration in 1960, Brussels did not shift its emphasis from improving free trade to protecting public health till $1975 .{ }^{68}$ The European Commission set up, in April 1974, a Permanent Scientific Committee on Food and, a year later, a Consultative Committee on Food with the aim of improving preconsultation with governments. Unlike economic regulations, which could remain "optional" in that national standards still applied to sales in the home country, health directives were to be "total", i.e., applicable to all food of a particular class in all member states. Total directives regulated food colouring in 1962 and milk in 1975, whereas red meat fell under optional regulations. Total directives about veterinary laws were introduced in March $1968 .{ }^{69}$

Although many EEC food safety regulations were a matter of consensus, the 1962 fruits and vegetables directive and the 1975 egg directive were majority decisions. These directives had been discussed and drafted in the framework of the Western European Union and the Codex Commission. As part of the Common Agricultural Policy, they fell under clause 43 of the Treaty of Rome. In general, France expressed strong opposition to this procedure in both EEC and Codex meetings. Let us take the

\footnotetext{
${ }^{67}$ Codex as a matter of consensus: Dobbert, op. cit., note 53 above, p. 701. This was a rather original procedure at the time, as compared with the Stresa Agreement about appellations d'origine and cheese trademarks (1 June 1951, implemented on 1 Sept. 1953), signed by Austria, Denmark, France, Italy, Norway, the Netherlands, Sweden, and Switzerland: Dobbert, op. cit., p. 704; Wright, op. cit., note 52 above, p. 83. Codex standards prevail: G Moore and A Tavares, 'Mesures récentes prises par l'Organisation des Nations Unies pour l'alimentation et l'agriculture en conséquence de l'Accord de l'Organisation Mondiale du Commerce sur l'application des mesures sanitaires et phytosanitaires', Ann. Franç. Droit Intern. 1997,
}

\author{
43: 544-50, on pp. 544, 548. EEC working \\ groups: Dr Lacambre, 5-7 Oct. 1960, op. cit., note \\ 64 above. \\ ${ }^{68}$ Health still ranks behind agriculture-whereas \\ the EU Agriculture Council meets monthly, the \\ Health Council is convened twice a year: Walzenbach, \\ op. cit., note 63 above, p. 70 . \\ ${ }^{69}$ Shift 1975: Welch, op. cit., note 34 above, \\ pp. 49-50. Permanent Scientific Committee on Food: \\ ibid., 54. Directives 1975, 1962, 1968: Welch, \\ op. cit., pp. 51-3, 81. The WHO/FAO Code of \\ Principles concerning Milk adopted similar rules \\ at the same time: FAO, op. cit., note 64 above, \\ p. 750 .
}


example of bovine growth hormones (BGH). Adopted in 1995 by a slim majority of four votes out of more than seventy government representatives, the Codex's hormone standard was cited by the WTO in its condemnation of EU measures against BGH. If the consensus rule could be tightened, such a misadventure could be avoided in the future. And in 1998, the Codex Commission lent more weight to the consensus rule by allowing standards to be improved by vote only after thorough efforts to obtain a consensus failed. As chair of the Committee on General Principles, France was instrumental in this change. The Codex Commission will now have to follow a complicated, time-consuming eight-step procedure in order to adopt standards. Backed by the French administration, it thus refused to examine a BGH standard in $1998 .^{70}$

Given the difficulty of adopting total directives by consensus, the European Commission, from 1973, resorted to "optional" regulations. This obliged it to admit that regional traditions and local customs have a bearing on the harmonization of food laws. From the very start, regional traditions lay at the heart of the principles guiding European policies on food colours and additives; and this did not make discussions any easier. At its second meeting in 1964, the Codex Commission-at the risk of undermining its own actions - declared that it approved the idea of regional standards. But then, had Austria, Belgium, France, Germany, Italy, Luxembourg, Spain and Switzerland not endorsed this idea with enthusiasm? It comes as no surprise that the president of the European Commission, Roy Jenkins, admitted in 1979 that harmonization was possible only in those areas where divergences were not too wide and problems not too complex. The uniformity achieved in the European Community between 1989 and 1994 mainly concerned techniques, such as monitoring production lines for disease-causing germs and chemicals, or networking salmonellae surveillance (SalmNet). ${ }^{71}$

This recognition of regional traditions and local customs led to "legitimate factors other than science" becoming more important. The SPS Agreement, a showpiece of historical, rationalistic ("Anglo-Saxon") liberalism, intended that science should play the key role so that food safety could be separated from high foreign policy. Detached from culture, the issue of food protection would thus depend on a single regulatorscience, the criterion for evaluating all other standards. This was, of course, either arrant naivety or cynicism. On the contrary, food and food safety are regional or cultural, far removed from any authoritative, universal principle but very close to local traditions and history. ${ }^{72}$ Like the rest of public health, as Peter Baldwin has convincingly

\footnotetext{
${ }^{70}$ Fruits, vegetables, and eggs: Welch, op. cit., note 34 above, p. 51. Consensus rule 1998: DGCCRF (1999), op. cit., note 59 above. BGH: Moore and Tavares, op. cit., note 67 above, p. 549; DGCCRF (1999), op. cit.; Refuse to examine: ibid.

${ }^{71}$ Optional solutions 1973: Welch, op. cit., note 34 above, pp. 56, 58. Local mores at the heart of principles: AN 880495 art. 8, note 57 above. Austria, etc.: Dobbert, op. cit., note 53 above, pp. 699-700, 691; FAO/66479, op. cit., note 53
}

above, p. 19. Jenkins: Welch, op. cit., p. 54. Monitoring production lines: Zylbermann, op. cit., note 48 above, p. 1. Salmonella: O Blond, 'Une salmonelle peut en remplacer une autre', $L a$ Recherche, 2001, no. 339: 38-9, on p. 39.

${ }^{72}$ This does not mean that food customs and traditions do not change. Witness the recent shift in the habits of certain fashionable Britons who now eat pork offal, a result of French pork exports to the United Kingdom: Milward, op. cit., note 59 above, p. 285 note 82 . 


\section{Patrick Zylberman}

argued, ${ }^{73}$ food safety is an issue where pluralistic values come into conflict. We should not, therefore, be surprised to observe that domestic politics has come back with a vengeance in the guise of the "precaution principle".

Without mentioning it by name, clause 20 of the Marrakech Treaty (15 April 1994) and clause 5 of the SPS Agreement do refer to precaution. Precaution turns out to be a legitimate principle in modern societies, which John Gray has rightly described as "unsupervised laboratories for an enormous, ongoing experiment in technological innovation". In such societies, precaution cannot keep science from being the key element in public policies. At present, the general public believes that food hazards are handled in the dark. Risk management implies more than assessing risks: assessments must also be made of risk-acceptability (i.e., the social perception of risk) and riskutility for the community at risk. Governments must not only supervise food safety policy but also provide guidance for the community's food supply. This is far from the protective role the state normally plays in food-related issues, since it implies that certain social, economic, psychological and cultural (and not just scientific) factors should legitimately enter into account when setting standards. The 1955 Conference on Food Additives recognized these implications even as it refused to take them into account. ${ }^{74}$ Although product-related rules for industrial, commercial and administrative practices may overlap with technical stipulations in Codex standards, the two may also be quite separate. But is not finding the fit between social values and safety standards - between norms and normalization-what the precaution principle might be all about ${ }^{75}$

\footnotetext{
${ }^{73} \mathrm{P}$ Baldwin, Contagion and the state in Europe 1830-1930, Cambridge University Press, 1999, pp. 2-15, 524-8.

${ }^{74} \mathrm{~J}$ Gray, Endgames: questions in late modern political thought, Cambridge, Polity Press, 1997, p. 184. Guidance to community: C Noiville, 'Principe de précaution et organisation mondiale du commerce. Le cas du commerce alimentaire', J. Droit Intern., 2000, 127: 263-97, on p. 288. Other legitimate factors: Noiville, ibid., pp. 289-90; A Martin, M Chambolle, C Badier, G Tufféry, 'L'expertise est-elle codifiable?', La Recherche, 2001, no. 339: 46-50, p. 49, in relation to the French Food Standards Agency. Conference 1955: FAO/ 66479 , op. cit., note 53 above, p. 8. State's usual role: for instance, the 1963 decree (J.O., 4 Aug. 1963) organizing the defences with regard to the food supply and food contamination.

${ }^{75}$ A few years after the Codex's first meeting, the French Ministry of Agriculture set up a work group to study "the whole range of issues raised by food" (Le Monde, 11 Nov. 1964). This group mainly concentrated on the population's needs (quantity of food), just as the Institut national de l'alimentation (created in 1936) did in response to the 25th Assembly of the League of Nations. Protecting consumer health became a goal in 1971, when the Secretary of State for Agriculture
}

aired a proposal for organizing two inspectorates for handling, respectively, pesticides and school restaurants (Le Monde, 24 May 1971). The government took a further step in 1976 when the Minister of Agriculture proposed gathering around the newly created Direction of Food Quality various inspectorates that were under the Ministry's veterinary branch (Le Monde, 18 March 1976). Twenty years later, following the "mad cow" panic, this same Ministry tried to expand its legal powers for inspection and "repression of fraud" (Les Échos, 11 Sept., 28 Nov. and 16 Dec. 1996; Le Figaro, 3 Dec. 1996). But what room was left for the Ministry of Health? This sensitive issue has never been addressed. The 1997 proposal for a food standards agency triggered a clash in parliament and between the two rivals, Agriculture and Health. This agency finally came into being on 26 March 1999. For further information about the French state's current role in food safety, see: Haut Comité de la Santé Publique, Pour une politique nutritionnelle de santé publique en France. Enjeux et propositions, Rennes, Éditions de l'École Nationale de la Santé Publique, 2000, ch. 5: 'Acteurs, structures et organisations impliqués dans le champ de la nutrition', pp. 163-83. 


\section{Making Food Safety an Issue}

Under pressure from food scares in the 1990s, EU officials tried to obtain recognition of the precaution principle from the Codex's Executive Committee in June 1998, the Codex's Committee on General Principles in April 1999, and within the frame of the Intergovernmental Working Party on Biotechnology in Derivative Foodstuffs created by the Codex Commission in 1999 and chaired by Japan. A few months later, Romano Prodi, the EC president, would declare food to be "part of Europe's cultural heritage". He thus made public health a supreme value to be incorporated in EU policy. ${ }^{76}$

To be sure, all this has added fuel to the dispute between Europe and the United States. The EU scored points at the inter-governmental conference on "International Food Trade after Year 2000" held in Melbourne in October 1999. This conference adopted a general recommendation for recognizing precaution as a "critical element" in drawing up Codex standards. (The twenty-first meeting of the Codex Commission had issued a statement of principles in 1995.) The Melbourne conference accepted the Codex's Committee on General Principles, chaired by France, as the appropriate forum for discussing "legitimate factors other than science" ${ }^{77}$ Cultural politics increasingly substitutes for functional politics.

To summarize the current situation, the fundamental misconception regarding the harmonization of pure food policies is to imagine that conflicts of values can be pushed aside by agreeing on technical and scientific standards. Science, it used to be believed, would provide principles dictating food safety standards, which judges need but apply. Little was left to political decision. Meanwhile, the food safety issue has ballooned, now obsessing public opinion-partly because of international tensions stemming from cultural differences. Border politics are still an option. Forced to adopt a get-along-go-along attitude in support of Brussels' standing food committees, angry ministry officials in France used to turn to border controls as a means of reasserting the state's role in food safety, at least for a while. It is, therefore, no surprise to discover that the first customs administration delegate (as well as one consumer representative) was appointed in 1973 to the French Ministry of Agriculture's Commission on Animal Feed. Yet another example: on 29 November 1975, parliament passed a law on veterinary drugs that forbids œestrogen abuse and fraudulent cross-border trade in antibiotics. ${ }^{78}$

Taking into account "legitimate factors other than science", the Codex Alimentarius is now trying to work out a modus vivendi with a plurality of conflicting interests and identities rather than leading painstaking negotiations with the aim of reaching a rational consensus on principles. The food safety issue challenges the idea that policies are ameliorated through a "spillover process that comes from cooperation in the rational solution of functional

\footnotetext{
${ }^{76}$ Speech by Romano Prodi, President of the European Commission, Plenary Session, European Parliament, Strasbourg, 5 Oct. 1999, Speech/99/121. A European Food Safety Authority was set up on 21 January 2002: EC Regulation no. 178/2002 of the European Parliament and of the Council.

${ }^{77}$ Melbourne Conference and Codex meeting: Noiville, op. cit., note 74 above, p. 293. Appropriate forum: DGCCRF (1999), op. cit., note 59 above.

${ }^{78}$ Get-along-go-along: AN 880495 art. 4: Dr Charbonneau [A Caillet], 'Note pour Monsieur
}

le Ministre', DGS/HP/2, 6 Oct. 1972. Customs delegate: Ministre de l'Agriculture [DuchêneMarullaz] au Ministre de la Santé Publique, RF-A1 81118, 1 Feb. 1973; Ministre de l'Agriculture [G-J Bernardy] au Ministre de la Santé Publique, RF-A1 82918, 12 May 1972. Estrogen and antibiotics: [Probably Dr A Caillet] handwritten notes [probably Apr. 1973], one recto-verso page: "La question de l'administration de certaines substances...", AN 880495 art. 4. A start was made at harmonizing European regulations about œstrogen and antibiotics in 1981. 


\section{Patrick Zylberman}

problems". Instead, it illustrates what I have proposed be described as "agonistic sanitarianism". As a science and an art based on practice, public health is a field for conflicts of interests and for competition between differing conceptions of the general interest. The simple belief that one single conception of health and safety is best for all cannot settle such conflicts. Cosmopolitical solidarities, though based on a defensive stance, are taking shape among the groups that discuss Codex standards. Under critical circumstances, "food wars", during which nations pursue divergent strategies in matters of health, animal as well as human, may none the less make borders important once again in the public estimation. ${ }^{79}$ The meat safety issue has come full circle.

${ }^{79}$ Spillover: Milward, op. cit., note 59 above, p. 12. Art: C E-A Winslow, The evolution and significance of the modern public health campaign, New Haven, Yale University Press, 1923, p. 1. Certain circumstances: W Drozdiak, 'Virus shuts Europe's open borders', International Herald Tribune, 16 March 2001. See the French Senate's report on the consequences of meat-and-bone meal for animal and human health: Le Figaro, 17 May 2001. 